\title{
Safeguarding innovation in the framework of sector-specific data access regimes: The case of digital payment services
}

\author{
Jörg Hoffmann
}

\section{A. Introduction}

The expected economic and social benefits of data access and sharing are enormous. ${ }^{1}$ Data-driven innovations have already transformed multiple sectors in the economy and are seen as a new disruptive source of productivity growth. In particular, the advanced use of data analytics and further applications of artificial intelligence (AI) enables undertakings to scale their business at much lower costs than in analogue times. ${ }^{2}$ Even beyond productivity growth, a greater availability of data can create beneficial spill-overs, where data can be re-used to open up further benefits and cost savings for society. ${ }^{3}$

In the European strategy for data, the European Commission addresses the need to ensure better availability of data and its responsible and efficient uses, as currently there are not enough data available for innovative re-use. Despite the current ongoing debate of further strengthening consumer data rights, particularly in a B2B context, data sharing of privately

1 According to one of the most recent studies conducted by the OECD, data access and sharing can help generate social and economic benefits worth between $0.1 \%$ and $1.5 \%$ of gross domestic product (GDP) in the case of public-sector data, and between $1 \%$ and $2.5 \%$ of GDP (in few other studies up to $4 \%$ of GDP) when also including private-sector data. See OECD, Enhancing Access to and Sharing of Data (OECD 2019) 60.

2 And this goes much beyond 'scaling without mass'. Cf. Erik Brynjolfsson, Andrew McAfee, Michael Sorell and Feng Zhu, 'Scale Without Mass: Business Process Replication and Industry Dynamics' (2008) Harvard Business School Technology \& Operations Management Unit Research Paper No. 7/16 <https://papers.ssrn.com /sol3/papers.cfm?abstract_id=980568 $>$ accessed 31 August 2020.

3 This ranges from greater transparency, accountability and empowerment of users, the creations of new business opportunities and user-driven innovations to increased efficiency due to a linkage and integration of data across multiple sources, OECD (n. 1) 64. 
held data between undertakings has not taken off at an efficient scale. ${ }^{4}$ This has already led to claims of lowering the competition law thresholds in data-specific refusal-to-deal cases and to the adoption of sector-specific data access and portability regimes in certain fields. ${ }^{5}$ It further drives the debate on how to foster private incentives for data sharing, e.g. by creating European data spaces fostering data interoperability or establishing data infrastructure like GaiaX. ${ }^{6}$

Yet, there might also be hidden costs and challenges of increased data sharing. The reaping of the advantages that come with enhanced data access requires the inclusion of the use of data in the business models of pri-

4 See for the discussion about consumer data rights OECD, 'Consumer Data Rights and Competition - Background note' (2020) DAF/COMP(2020)1 <https://one.oec d.org/document/DAF/COMP(2020)1/en/pdf > accessed 31 August 2020, which was triggered by their introduction through legislation in Australia - see Louisa Specht-Riemenschneider in this volume. Cf. Communication from the Commission of 19 February 2020 to the European Parliament, the Council, the European Economic and Social Committee and the Committee of Regions - A European strategy for data, $\operatorname{COM}(2020) 66$ final, 3, 6, 7.

5 Cf. Jacques Crémer, Yves-Alexandre de Montjoye and Heike Schweitzer, 'Competition Policy for the Digital Era - Final Report' (2019) 91-107<https://ec.europa.eu/ competition/publications/reports/kd0419345enn.pdf> accessed 31 August 2020, and see Heike Schweitzer and Robert Welker, 'A legal framework for access to data - A competition policy perspective', in this volume. Such fields are for instance repair data for vehicles - Regulation (EC) 715/2007 of the European Parliament and of the Council on type approval of motor vehicles with respect to emissions from light passenger and commercial vehicles (Euro 5 and Euro 6) and on access to vehicle repair and maintenance data [2007] OJ L171/1, as amended by Regulation (EU) 595/2009 of the European Parliament and the Council of 18 June 2009 [2009] OJ L188/1, smart metering information - Directive (EU) 2009/73 of the European Parliament and of the Council of 13 July 2009 concerning common rules for the internal market in natural gas and repealing Directive 2003/55/EC [2009] OJ L211/94, electricity network data - Directive (EU) 2019/944 of European Parliament and of the Council of on common rules for the internal market for electricity and amending Directive 2012(27/27/EU [2019] OJ L158/125, or electricity transmission Commission Regulation (EU) 2017/1485 of 2 August 2017 establishing a guideline on electricity transmission system operation [2017] OJ L220/1, intelligent transport systems - Commission Regulation (EU) 2015/703 of 30 April 2015 establishing a network code on interoperability and data exchange rules [2015] OJ L113/13.

6 Cf. European Commission, 'A European strategy for data' (n. 4) 4; on the joint hybrid endeavour of the French and German Government together with private stakeholders Gaia X see Federal Ministry of Economics Affairs and Energy, 'GAIA $\mathrm{X}$ - A Federated Data Infrastructure for Europe' <www.bmwi.de/Redaktion/DE/Do ssier/gaia-x.html > accessed 31 August 2020; on the standardisation of web information, i.e. linked data, see World Wide Web Consortium (W3C), 'Linked Data' $<$ www.w3.org/standards/semanticweb/data $>$ accessed 31 August 2020. 
vate actors. This makes complementary investments in skills and infrastructures necessary, which may potentially exclude traditional market actors. ${ }^{7}$ Moreover, data entail multidimensional regulatory goals. Exclusively held data can offer an enormous competitive advantage and may be one of the innovation incentives for undertakings. On the other side, data lock-ins and excessive aggregation of data can also have negative effects on competition. Data can also consist of personal information that can be used in such ways that might not only create societal change, it might also impact the sovereignty of consumers and their privacy. Another factor that has to be considered is that the freedom of information and the free flow of information are prerequisites for a democratic society.

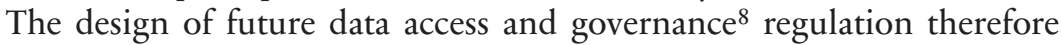
requires a broad regulatory theory that takes into account all the different implications of a wider data access regime. ${ }^{9}$ Only a holistic assessment of the overall regulatory goals may make consistent regulation of data access possible and feasible.

Accordingly, the paper firstly outlines the role factual data exclusivity plays in light of the broad regulatory theory mentioned above and thus will also relate to other market failures that at first sight may be solved within other legal regimes, i.e. data protection law, consumer protection law or (general) competition law. Even under the sole analysis of a market failure with regard to data-driven innovation capacities of a European Single Data Market, such considerations may ultimately also define the ideal legal framework for data access in order to better enable data-driven inno-

7 Peter A. Johnson and others, 'The Cost(s) of Geospatial Open Data' (2017) 21 Transaction in GIS 434, 442.

8 The term 'data governance framework' relates to a complex set of rules (laws and standards) relating to data. In the payments sector for example public laws establish ex ante regulation that require pre-set corporate data management solutions in firms. The regulation on regulatory technical standards set out certain interoperability provisions, which compliance need to be monitored by the competent administrative authorities. The introduction of certain rights of payment service users however are private laws that define the contractual relationship of the parties involved. Both forms of regulation are defining the data access regime for the use of specific payment services. On the term 'data governance' from a corporate governance and IT perspective, see Boris Otto, 'Data Governance' (2011) 3 Business \& Information Systems Engineering 241. See also Kerber 'From (horizontal and sectoral) data access solutions - Towards data governance systems', in this volume.

9 Cf. Josef Drexl, 'Legal Challenges of the Changing Role of Personal and Non-Personal Data in the Data Economy' (2018) Max Planck Institute for Innovation and Competition Research Paper No. 18-23, $6<$ https://papers.ssrn.com/sol3/papers.cf m?abstract_id=3274519> accessed 31 August 2020. 
vation. There are at least four aspects that must be always considered: (1) setting innovation incentives for undertakings; (2) the role of direct market regulation; (3) ensuring consumer sovereignty and choice; (4) hindering data-induced distortions of competition.

In this light, the paper further analyses the sector-specific data access regulation pertaining to payment initiation and account information services enshrined in the Second Payment Services Directive ${ }^{10}$ (PSD2) and implemented into German law. It will analyse whether the legal access regimes are well designed for safeguarding (data-driven) innovation and how the different regulatory goals and the public and private interests are addressed and should be better aligned. It will be seen that the implementation of the access rules in both private and public laws cause certain tensions and create legal uncertainty as the legal rights and obligations between third party payment providers and incumbent banks are not well outlined but still influenced by the private statutory right of customers including consumers and merchants - to make use of certain payment services. Nonetheless it will be shown that the chosen data governance model could serve as regulatory model for safeguarding data driven innovation that can be applied to other already existent and future (sector-specific) data access and portability regimes. The paper concludes by contrasting the findings with the EC's recent data strategy. It does not analyse the data access and governance regime for payment instrument issuing services and only briefly outlines the role of data interoperability that may affect the potential adverse effects of too broad access regimes. Furthermore, it does not analyse the current endeavours for fostering voluntary data sharing.

\section{B. Defining a holistic framework for data access regimes}

\section{Data-driven innovation capacities of markets and factual data exclusivity}

The availability of data is certainly one of the main driving factors for establishing a functioning and competitive digital single market. The role of factual data exclusivity, however, may also serve as a private innovation incentive for undertakings to invest in data production and analysis. This

10 Directive (EU) 2015/2366 of the European Parliament and of the Council of 25 November 2015 on payment services in the internal market, amending Directives 2002/65/EC, 2009/110EC and 2013/36/EU and Regulation (EU) No 1093/2010 and repealing Directive 2007/64/EC [2015] OJ L337/35 (PSD2). 
again could not only spur data-driven innovations, it could also make the regulation of quality standards for data less important. Once markets value higher quality data, there will be demand-side-driven incentives for providing quality data. ${ }^{11}$ In this context it is important not to mix up data exclusivity with a need for introducing further exclusive rights. A few economists and legal scholars are already inclined to think that well-defined and easily enforceable data ownership rights were an efficient way to organise the data-driven economy. ${ }^{12}$ Exclusive rights in data would reduce uncertainty and the margins for bargaining. This in turn would reduce transaction costs that create deadweight welfare losses for society and ultimately tackle a public good market failure. ${ }^{13}$ Despite these potential benefits, one has to negate the need for an ownership right. This is not only because transaction costs would hinder the ideal allocation of rights, but also because factual exclusivity may already create enough incentives for undertakings to invest and therefore no public good market failure exists. However, if factual excludability may now be overridden by regulating too broad access to data, the question of how to balance (factual) exclusivity in order to safeguard innovation incentives for undertakings and ensure adequate access for value-creating data re-use is inevitably arising again. This also becomes relevant from a fundamental rights perspective, as different

11 This could also be established via a certain label for specific quality data in order to avoid a typical lemon market scenario.

12 See Daron Acemoglu, Ali Makhdoumi, Azarakhsh Malekian and Asuman Ozdaglar, 'Too Much Data: Prices and Inefficiencies in Data Markets' (2019) NBER Working Paper No. 26296 <www.nber.org/papers/w26296> accessed 31 August 2020; Karl-Heinz Fezer, 'Dateneigentum - Theorie des immaterialgüterrechtlichen Eigentums an verhaltensgenerierten Personendaten der Nutzer als Datenproduzenten' (2017) MultiMedia und Recht 1. On a thorough analysis of why no ownership rights are needed and the creation of an ownership right would have adverse effects Josef Drexl, 'Designing competitive markets for industrial data: Between propertization and access' (2017) 8 Journal of Intellectual Property, Information Technology and E-Commerce Law 257, paras 74, 81, 89, 91, 93, 103 et seq.

13 Yet what has to be noted is that such considerations build on the (wrong) assumption of the Coase Theorem that any a priori given IP right eventually will end up in the hands of the party that attaches the most value to these resources, leading towards an ideal allocation of intellectual property rights. Where transaction costs are rather high with regard to the value of the right, these considerations do not apply. New Institutional Economics already assessed this. However, high transactions in relation to the value of the right would resemble big data scenarios and therefore should not be taken as an economic rationale for the creation of exclusive rights in data. Cf. Ronald H. Coase, 'The Problem of Social Costs' (1960) 3 Journal of Law \& Economics 1, 44. 
interests are protected under the Charter of Fundamental Rights of the EU (CFR) and thus also need to be reconciled with the goal of fostering datadriven innovation.

\section{Applying IP Economics in data access cases - the innovation incentive of factual data exclusivity}

Factual data exclusivity may serve as innovation incentive for undertakings and thus the considerations of intellectual property rights (IPRs) economics also become relevant. ${ }^{14}$ The standard economic model of IPRs is based upon a utilitarian incentive theory. ${ }^{15}$ This theory revolves around the trade-off between static social welfare losses from over-protection of exclusivity and dynamic welfare gains achieved through the incentive effect for more investment in production of creative or innovative content. ${ }^{16}$ Translated into the data access context this would mean that the incentive effects of factual data exclusivity and exclusive endogenous data-driven innovation need to be reconciled with the spill-over effects of available data for everyone.

The basic economic rationale behind IPRs is that the static short-term welfare loss is compensated by dynamic long-run gains generated by a continuous stream of new creations and innovations. This is only possible as IP rights allow the right owners to recoup their investments without potential free riders being able to sell the same product. The key consideration behind this would be to block others from entering the market unless the rights holder licenses the rights, and thus to reduce intra-brand competition. The same market-specific reasoning of IPRs can only be applied to data once data are essential facilities, and become relevant under market foreclosure considerations. The application of the essential facilities doc-

14 Wolfgang Kerber, 'A New (Intellectual) Property Right for Non-Personal Data? An Economic Analysis' (2016) Gewerblicher Rechtsschutz und Urheberrecht Internationaler Teil 989, 993; Nestor Duch-Brown, Bertin Martens and Frank Müller-Langer, 'The economics of ownership, access and trade in digital data' (2017) JRC Digital Economy Working Paper 2017-01, 25-29 < https://ec.europa.e u/jrc/sites/jrcsh/files/jrc104756.pdf > accessed 31 August 2020.

15 Cf. Richard A. Posner, Economic Analysis of Law ( $7^{\text {th }}$ edn, Wolters Kluwer 2007) 38. Steven Shavell, 'Economic Analysis of Welfare Economic, Morality and the Law' (2003) NBER Working Paper No. 9700, $669<\mathrm{https} / /$ ideas.repec.org/p/nbr/n berwo/9700.html> accessed 31 August 2020.

16 See William D. Nordhaus, Invention, Growth, Welfare: A Theoretical Treatment of Technological Change (MIT Press 1969) 71. 
trine in these cases however may have to be broader defined and should not be restricted to traditional indispensability considerations of exclusive information. Data specific economies of scope may also lead to such knowledge of firms that constitute a competitive advantage that in the very end has the same market foreclosing effect as indispensable exclusive information. The knowledge inferred from multiple data sets may constitute such an advantage that others may simply not be able to achieve anymore. Yet data can also only be mere by-products that lack certain economic value - particularly in the context of IoT.

The potential excludability that would result from the creation of an ownership right on data would hinder the further use of the data. According to new institutional IPR economics, the welfare-enhancing effects of exclusivity might dwindle if IP rights preclude independent subsequent creation and innovation that build on the protected input. ${ }^{17}$ This is also true in light of potential negative externalities that also relate to lower investment incentives for undertakings. ${ }^{18}$ Yet the fact that tomorrow's innovators can benefit from 'standing on the shoulders of giants', ${ }^{19}$ while potentially not sharing gains with their predecessors, makes a nuanced assessment of the 'free-rider' issue necessary.

Data availability may enable subsequent use of data within the data value chain or network, and thus may create further data-driven innovation. ${ }^{20}$ In this context, however, it has to be noted that any innovation requires

17 Jeffrey L. Furman and Scott Stern, 'Climbing atop the Shoulders of Giants: The Impact of Institutions on Cumulative Research' (2011) 101 American Economic Review 1933; Heidi L. Williams, 'Intellectual Property Rights and Innovation: Evidence from the Human Genome' (2014) 121(1) Journal of Political Economy 1; Paul M. Romer, 'Endogenous technological change' (1990) 98(5) Journal of Political Economy 71, 71-75.

18 Kenneth J. Arrow, 'Economic Welfare and the Allocation of Resources for Invention' in National Bureau of Economic Research, 'The Rate and Direction of Inventive Activity: Economic and Social Factors' (Princeton University Press 1962) 609, 620. Different opinions on this: Joseph Schumpeter, Theorie der wirtschaftlichen Entwicklung (Duncker \& Humblot 1912) 157 and Philippe Aghion and Peter Howitt, 'A model of growth through creative destruction' (1992) 60(2) Econometrica 323.

19 Suzanne Scotchmer, 'Standing on the Shoulders of Giants: Cumulative Research and the Patent Law' (1991) 45(1) Journal of Economic Perspectives 29, 29-30.

20 Most data-driven innovation is enabled by the use of artificial intelligence. In this regard particularly software copyright protection for machine learning models becomes relevant, as it may also block further subsequent data-driven innovation. See on this Reto M. Hilty, Jörg Hoffmann and Stefan Scheuerer, 'Intellectual Property Justification for Artificial Intelligence' (2020) Max Planck Institute for 
something new or improved that actually gets implemented. ${ }^{21}$ This not only means that data need to be consolidated or aggregated in order to further infer some information, but such information also has to add something new on the knowledge level. Therefore, the mere gathering of data without making proper use may not constitute a data-driven innovation and one needs to be cautious as to whether data-driven innovation is used to an inflationary extent for justifying access to data.

In order to ascertain the right scope of excludability, or in other words the right relationship between factual exclusivity and data access, the economic model build by Zhu et al. can serve as a good starting point. Accordingly, the following factors ${ }^{22}$ should be assessed: (1) fixed investment costs in the production, processing and analysis of data; (2) the likelihood of potential free-riders exceeding the marginal benefits of data producers and holders; ${ }^{23}$ and (3) functional equivalence between the re-used data and the (factual) exclusive data. ${ }^{24}$

With regard to the investment cost, the empirical facts show that in the data-driven economy much data can be produced or collected at very low

Innovation and Competition Research Paper No. 20-02, $25<$ https://papers.ssrn.c om/sol3/papers.cfm?abstract_id=3539406> accessed 31 August 2020.

21 The $3^{\text {rd }}$ edition of the Oslo Manual defines innovation as the implementation of a new or significantly improved product (good or service), or process, new marketing method, or new organisational method in business practices, workplace organisation or external relations. See OECD, 'Oslo Manual: Guidelines for Collecting and Interpreting Innovation Data' (2005) 1, 45. Data-driven innovation can thereby happen in all the different categories and take place in data value cycles. Therein data are firstly collected, then analysed, knowledge inferred and then applied in the decision-making process. See OECD, 'Data-Driven Innovation: Big Data for Growth and Well-Being' (OECD 2015) 33.

22 These simplified factors resemble the key economic considerations new institutional IPR economics are built on and relate to the economic model Zhu and others developed in their economic analysis pertaining to the functionality of the sui generis database protection regime. See Hongwei Zhu, Stewart E. Madnick and Michael D. Siegel, 'An Economic Analysis of Policies for the Protection and Reuse of Non-copyrightable Database Contents' (2008) 25(1) Journal of Management Information Systems 199. Indeed, even though the database sui generis right only protects the substantial investments made in obtaining or verifying existing data and not in the creation of data, it can still serve as reference for mere investment protection considerations.

23 From an economic point of view, it can be expected that data are produced and analysed as far as the marginal benefits of the data producers and holders exceed their marginal costs. See Kerber (n. 14) 993.

24 Translated into a competition law perspective this would mean complementarity or substitutability under essential facility considerations. 
costs, often only as a free by-product of offered services. ${ }^{25}$ However, the costs vary depending on the type of data (e.g. unstructured, semi-structured vs. structured data). ${ }^{26}$ Particularly extracting information from unstructured data used to be labour-intensive. With growing computing capacities, however, such differentiation is becoming less important, since data analytic tools are increasingly able to automatically extract the information embedded in unstructured data. Nonetheless specifically labelled data is still important, and still labour-intensive and costly. ${ }^{27}$ Moreover, data governing and transmitting costs can also be substantial. ${ }^{28}$

With regard to the extent of functional equivalence between the re-used data and the original exclusive data, it may be hard to assess to what extent a data-driven innovation exists and whether this can be considered as a substitute for or complementary to the original data or data-driven service. ${ }^{29}$ This holds particularly true in AI applications, where specific machine learning (ML) models may build on multiple data throughout the learning process. The quality of the ML model is commonly claimed to be dependent on multiple data from many different sources in order to better train and optimise the model. In both cases, it seems on first sight that any data would enhance data-driven innovation, as the output of the ML process will never be simply equivalent to the original data. However, only data that are (partly) related to each other can improve ML models. ${ }^{30}$

25 Duch-Brown, Martens and Müller-Langer (n. 14) 25-29.

$26 \operatorname{Kerber}($ n. 14) 993.

27 There are high costs for labelling data in the context of supervised learning in deep learning applications. See WIPO, 'Technology Trends 2019: Artificial Intelligence' (WIPO 2019) 89.

28 E.g. secure and common standards of communication require investments in an in-house IT infrastructure or technology developers (with regard to APIs). Other costs relate to cloud services or data standardisation. See on the costs for instance Marc Walterbusch, Benedikt Martens and Frank Teuteberg, 'Evaluating cloudcomputing services from a total cost of ownership perspective' (2013) 36 Management Research Review 613. See on an overview of different data quality categories and the already existent standards under the ISO-8000 data standard, Li Cai and Yangyong Zhu 'The Challenges of Data Quality and Data Quality Assessment in the Big Data Era' (2015) Data Science Journal 5-9 < https://datascience.codata.org/ articles/10.5334/dsj-2015-002/print/> accessed 31 August 2020.

29 Once the data is used and the coding team creates something of equal or even better value that would be a substitute to the existent data or data-driven service, there will be less incentive for the company to further invest in data.

30 Looking for structures and regularities in data is not enough to understand or acquire knowledge. Knowledge cannot be derived through induction alone; it requires a theory or a prior framework that can be tested. Humans necessarily pre- 
2. Legal Framework of essential facilities - EU competition law, EU utilities market regulation in the telecommunication sector and EU fundamental rights

Under legal considerations, in cases in which IP rights create legal exclusivity to offer market options for boosting dynamic (inter-brand) competition, the European case law with regard to Article 102 lit. b) TFEU and unilateral exploitation of IP rights has always been restrictive. At first, the CJEU in its Volvo decision set out the general principle that the right of the holder of an IPR to make exclusive use of it is precisely the substance of the exclusive right. Therefore, the mere refusal to license the IPR - even if the terms were reasonable - was held to be, in principle, no abuse of dominant position. ${ }^{31}$ Yet, the CJEU allowed the European Commission in the judgment of Magill to rely on competition law for overcoming non-availability under copyright law. Accordingly, only exceptional circumstances require access on the basis of Article 102 lit. b) TFEU in order to prevent a unilateral restriction of production, sale or technical development to the detriment of consumers once an IP right owner refuses to grant a licence and, a fortiori, is bringing an action for infringement. The presence of exceptional circumstances is according to the CJEU in Magill ${ }^{32}$ subject to the following four requirements: (1) the licensing must be indispensable for access to the downstream market, (2) the refusal to grant a licence must exclude any effective competition in this market, (3) the refusal to grant a licence must prevent appearance of a new (but dependent) product on an adjacent market which it does not supply itself, and (4) the refusal to license must not be objectively satisfied by way of exception. According to the CJEU in IMS Health the requirements must be cumulatively satisfied. However, the Court also found that a hypothetical market would suffice to meet the exceptional circumstances threshold. ${ }^{33}$

determine this framework and thus data have to be related - at least to some extent. See Ronaldo Vigo, 'Complexity over uncertainty in generalized representational information theory (GRIT): A structure-sensitive general theory of information' (2013) 4 Information 1.

31 Case 238/87 Volvo [1988] ECR 6211 = ECLI:EU:C:477, para. 8.

32 Joined Cases C-241/91 and C-242/91 RTE and ITP v. Commission ('Magill') [1995] ECR I-743 = ECLI:EU:C:1995:98, paras 39-42.

33 Case C-418/01 IMS Health [2004] ECR I-5039 = ECLI:EU:C:2004:257, paras 34, 44. 
Particularly by stressing the 'new product rule' the CJEU in Magill ${ }^{34}$ and - despite the hypothetical market exemption - IMS Health ${ }^{35}$ correctly followed the role competition law traditionally plays in IP law. In unilateral refusal-to-deal cases, competition law ought to safeguard the goal of interbrand competition generated by IP rights and therefore abstain from interfering with the terms or the operation of the IP system per se. Only where IP law fails to provide for dynamic inter-brand competition may competition law serve as a complementary tool in order to safeguard the well-functioning of markets that are enabled by IP rights. In other words, Article 102 TFEU is in general not meant to enforce direct market access to allow mere intra-brand competition by imitation and restrict competition on the merits. ${ }^{36}$ This would contradict the role competition law plays within a free market economy, where markets typically evolve spontaneously and are only framed by a competitive process that should be safeguarded by competition law rules.

In cases of refusal to disclose trade secrets ${ }^{37}$ or supply access to other exclusive facilities ${ }^{38}$ however, the CJEU explicitly abstains from the traditional delineation of intra-brand and inter-brand competition and lowered the threshold of intervention. Yet, it still outlines the role exclusivity plays under innovation incentive considerations and the defendants' rights of freely conducting a business. In Bronner, for instance, the Court found no abuse of dominance, as the facility - a home-delivery service for newspapers - was already not indispensable and could be developed by other competitors. ${ }^{39}$ There the Court stressed the particular need of maintaining innovation incentives for undertakings in order to safeguard competition in the long term. ${ }^{40}$ However, in Microsoft, the General Court desisted from

34 Joined Cases C-241/91 and C-242/91 RTE and ITP v. Commission ('Magill') [1995] ECR I-743 = ECLI:EU:C:1995:98, paras 39-42.

35 Case C-418/01 IMS Health [2004] ECR I-5039 = ECLI:EU:C:2004:257, para. 48. Therein, the Court underlined 'that, in the balancing of the interest in protection of the intellectual property right and the economic freedom of its owner against the interest in protection of free competition, the latter can prevail only where refusal to grant a licence prevents the development of the secondary market to the detriment of consumers.'.

36 Torsten Körber, Standardessentielle Patente, FRAND-Verpflichtungen und Kartellrecht; Standard Essential Patents, FRAND Commitments and Competition Law, Kartell-und Regulierungsrecht (Nomos 2013) 212-14.

37 Case T-201/04 Microsoft v. Commission [2007] ECR II-3602 = ECLI:EU:T:2007:289.

38 Case C-7/97 Bronner [1988] ECR I-7791 = ECLI:EU:C:1998:569.

39 Opinion of AG Jacobs in Case C-7/97 Bronner ECLI:EU:C:1998:264, para. 57.

40 Ibid. 
the strict requirement of the new product rule in a secondary market set out in Magill and IMS Health and allowed access even if it may only create competition within the primary market. Therein, the Court held that the exclusivity of interoperability information is tantamount to an abuse of dominance under Article 102 lit. b) TFEU. The Court stated that the new product rule 'cannot be the only parameter'. The relevant question is rather whether the refusal to grant a licence will limit technical development to the detriment of the consumers. ${ }^{41}$ This requirement was considered to have been met because the lacking interoperability of the competitors' software would bind customers to Microsoft and prevent competitors from successfully selling their innovative products and thus from entering a market. This would tantamount to an exclusionary abuse constellation. According to the Court's opinion in Microsoft, it indeed seems not to matter anymore whether access to the facility enables innovation on a secondary market (downstream market), but whether innovation per saldo is actually increased or not. ${ }^{42}$ This applies to both the prospect of incremental innovation within the already existent market and radical innovations on a secondary - even hypothetical - market. By taking per saldo innovation into the equation of Article 102 lit. b) TFEU the Court has given up the clear distinction between competition within the market and competition for the market. Applied to the question of how to draw the line between factual data exclusivity and access, such interpretation would constitute an argument in favour of a broader data access regime - if the information needed are indispensable for achieving interoperability.

In the case of de facto standardisation, exclusivity of interoperability information has effects on dynamic competition in the long run. Exclusivity in these cases may eventually lead to a market foreclosure on both the already existent and the adjacent markets. This holds particularly true in systems markets, where product compatibility connects the neighbouring markets in such a way that a decrease in competitive pressure and competitive process on the primary market may eventually cause dynamic competition and its innovation effects to deteriorate. ${ }^{43}$ Under this theory of contestability the intervention is justified. However, even in Microsoft, it was

41 Case T-201/04 Microsoft v. Commission [2007] ECR II-3602 = ECLI:EU:T:2007:289, para. 647.

42 As innovation always requires implementation and is hard to measure, such reasoning creates much legal uncertainty. See Körber (n. 36) 212-14.

43 Heinemann refers to this under the theory of contestability, according to which vertical, but also neighbouring, markets that are anti-competitively foreclosed by a dominant undertaking must remain contestable. Andreas Heinemann, 'The 
considered whether the competitors' products included 'substantial elements based upon the [competitors'] own efforts'. ${ }^{44}$ This is at least some reference to the need of also limiting imitation (intra-brand) competition in these cases. The General Court also considered Microsoft's argument that the compulsory licensing of data would eliminate its future incentive to further invest in innovation. Yet the Court dismissed it, purportedly, with the reasoning that the particular role of disseminating the de facto technical standard has to prevail over the interests of Microsoft in the case. $^{45}$

The particular role of standardisation and exclusivity in competition law can also be seen in cases concerning standard-essential patents (SEPs) where standards are established by way of open standardisation processes through standard setting organisations (SSOs). ${ }^{46}$ Even though this system is one that falls under 'regulatory self-regulation', wherein the scope of the SEP is determined by FRAND (fair, reasonable and non-discriminatory) licensing commitments, the CJEU in Huawei outlined the role of Article 102 TFEU for examining the FRAND terms for cases where the proprietor of the SEP brings a legal action against the contracting partner for infringement.

The Court dismissed the right of the SEP owner to exclude the infringer. It ruled that the voluntary act of exploiting a patent via open standardisation justifies the imposition on the proprietor of an obligation to comply with specific requirements when bringing actions against an alleged infringer for a prohibitory injunction or for the recall of products. ${ }^{47}$ SEPs in open standardisation processes are per se indispensable to all competitors, which envisage manufacturing products that comply with the

contestability of IP-protected markets' in Josef Drexl (ed.), Research Handbook on Intellectual Property and Competition Law (2008) 54. See also Josef Drexl 'Intellectual property and sources of market power' in Inge Govaere and Hanns Ullrich (eds), Intellectual Property, Market Power and the Public Interest (2008) 13.

44 Case T-201/04 Microsoft v. Commission [2007] ECR II-3602 = ECLI:EU:T:2007:289, para. 631.

45 This also led to criticism of the Microsoft case being driven by policy considerations regarding the technological dissemination of certain standards. Gustavo Ghidini, Rethinking Intellectual Property - Balancing Conflicts of Interest in the Constitutional Pradigm (Edward Elgar 2018) 339-41.

46 Cf. Hanns Ullrich, 'Technology protection and competition policy for the information economy' (2019) Max Planck Institute for Innovation and Competition Research Paper No. 19-12, $8<$ https://papers.ssrn.com/sol3/papers.cfm?abstract_id $=3437177>$ accessed 31 August 2020.

47 Case C-170/13 Huawei ECLI:EU:C:2015:477, para. 59. 
standard to which it is linked. Accordingly, the Court held that this was already tantamount to an abuse under Article 102 TFEU, ${ }^{48}$ as the case was different from Volvo, Magill or IMS Health. ${ }^{49}$

By rejecting the right of exclusivity, however, the Court implicitly establishes markets where competition only between standard-compliant products becomes the prevalent form of competition. Here it becomes obvious that the innovation-incentivising role of IP is again reoriented towards facilitating the dissemination of the open innovative standard in order to establish intra-standard competition. ${ }^{50}$ Therefore, Huawei Technology/ZTE may indeed be seen as a case in which the Court abandons the traditional role of exclusivity in favour of granting broader access - in this case by denying the proprietor of an SEP in open standardisation processes injunctive relief. Yet what has to be considered in this case is the particular role the voluntary FRAND commitment plays in open standardisation processes and the potential effects of the commitment in rem.${ }^{51}$ Accordingly, a voluntary act that led to the indispensability of the SEP justifies a lower threshold for granting access.

Non-economic considerations, namely equity-based universal service, redistributive objectives and political inclusion has compelled the legislature to enact market regulation. This could already be seen in the post service and telecommunication sectors throughout the European integration process in the late $1980 \mathrm{~s}$ and early $1990 \mathrm{~s} .{ }^{52}$ In the telecommunication sectors, for instance, these factors together with a natural monopoly market failure associated with high levels of monopolisation stemming from traditional state monopolies led to regulatory responses that granted universal access

48 Ibid. para. 53.

49 Ibid. para. 49.

50 See Ullrich (n. 46) 8; Ghidini (n. 45) 339. Giuseppe Colangelo and Roberto Pardolesi, 'Intellectual property, standards and antitrust: A new life for the essential facilities doctrine?' (2017) in Gustavo Ghidini, Hanns Ullrich and Peter Drahos (eds), Kritika - Essays on Intellectual Property (Vol. II, Edward Elgar 2017) 70.

51 Ullrich therefore argues that the Court's consideration rather builds on the FRAND commitment by the SEP owner and competition law only intervenes in order to observe the FRAND negotiation process and the FRAND conditions. See Ullrich (n. 46) 16. It still has to be considered though which doctrinal basis such considerations are really built on - estoppel, good faith or material agreement with a pactum di non petendo.

52 Cf. Jürgen Bast, in Eberhard Grabitz, Meinhard Hilf and Martin Nettesheim (eds), Das Recht der Europäischen Union (C.H. Beck 2011) Art. 26 AEUV para. 8, Hans-Wolfgang Arndt, Kristian Fischer and Thomas Fetzer, Europarecht (C.F. Müller 2010) 28. 
to telecommunication infrastructure below competition law thresholds. Asymmetric ex ante access provisions guaranteed access to telecommunication services to all parts of the country (regardless of low-cost or high-cost customers). The costs were unilaterally borne by the incumbents in the very beginning. ${ }^{53}$

This - asymmetric - universal service obligation left the incumbents with competitive disadvantages, particularly as other competitors could freely choose to only provide services to low-cost customers. ${ }^{54}$ This was justified, because there was - similar to the open standardisation cases - already an indispensability of the facility that did not stem entirely from the undertakings' endeavours. The facility was derived from a state monopoly, which is not necessarily the case in a typical B2B data sharing context. ${ }^{55}$ Throughout the years, however, technical developments and innovations in the telecommunication markets increased competition and reduced the need for strong market regulation. The open-access regulatory approach transitioned to a strategy of deregulation, which seeks to limit access regulation to abuse-of-dominance cases. It is thus now focused on realigning sector-specific access regimes with the general competition law thresholds, emphasising the need for protecting investment incentives of undertakings. ${ }^{56}$

This analysis shows that the trend over time has been towards granting broader access. Nonetheless the economic criteria outlined above should not be overseen and be well aligned with the prevailing view of the European competition law case law if it comes to data access market regulation. ${ }^{57}$ Utilities regulation - under data as infrastructure considerations -

53 On the development of telecommunication regulation in light of privatisation and harmonisation see Thomas Fetzer, Staat und Wettbewerb in dynamischen Märkten (Mohr Siebeck 2013) 145.

54 See Peter Alexiadis and Martin Cave, 'Regulation and Competition Law in Telecommunications and Other Network Industries' in Robert Baldwin, Martin Cave and Martin Lodge (eds), The Oxford Handbook of Regulation (2010) 500, 504506.

55 In this context, however, it again depends on the data at stake. The case needs to be differently assessed in Public Sector Information cases for instance.

56 See Art. 8(5) lit. d), Directive 2009/140/EC of the European Parliament and of the Council of 25 November 2009 on a common regulatory framework for electronic communications networks and services [2009] OJ L337/37. On the antinomy of regulation and competition law in natural monopoly cases see Ernst-Joachim Mestmäcker, 'Private Macht - Grundsatzfragen in Recht, Wirtschaft und Gesellschaft' in Florian Möslein (ed.), Private Macht (Mohr Siebeck 2016) 25, 42.

57 This was already emphasised by the European Commission in its Communication on Building a European Data Economy. Despite outlining the need for enhanced 
typically build on natural monopoly market failures and thus can only serve as a reference point in similar cases.

It should be kept in mind that under specific dynamic competition considerations and the theory of contestability, a broader access regime under which the licensing of data tackles incontestable market dominance of the current undertakings with paramount importance for competition across markets seems justified.58 This approach should not be mixed up with mere policy considerations of directly spurring other public interests (i.e. interoperability in order to further create intra-standard innovations). ${ }^{59} \mathrm{In}$ this case, competition law runs the risk of being instrumentalised as a tool of direct market intervention, which eventually marginalises the undertakings' interests to further invest and illegitimately hampers the core function of markets, namely to establish efficient product allocation and dynamic competition that leads to innovation - this applies to data-driven innovation too. ${ }^{60}$

It should be further noted that factual data exclusivity may also become relevant under a fundamental rights perspective, notably with regard to the right of intellectual property, Article 17(2), (1) CFR - where data is protected subject matter of IP rights ${ }^{61}$ - and the right to freely conduct a business, Article 16 CFR. This not only refers to the question of granting access or not, but also to the right of exploiting the granting of access. ${ }^{62}$ Thus, before defining too heavy-handed access modalities one needs to consider that this further contradicts the principle of contractual freedom, may infringe the undertakings' fundamental rights and may lead to distor-

data access, the relevant legitimate interests, as well as the need to protect trade secrets, would need to be taken into account. See Communication from the Commission of 10 January 2017 to the European Parliament, the Council, the European Economic and Social Committee and the Committee of the Regions 'Building a European data economy' $\operatorname{COM}(2007) 9$ final, 13.

58 Cf. Carsten Herresthal, 'Private Macht im Vertragsrecht - Austauschverträge', in Florian Möslein, Private Macht (Mohr Siebeck2016) 146, 157.

59 Cf. Wolfgang Kerber and Heike Schweitzer, 'Interoperability in the Digital Economy' (2017) 8 Journal of Intellectual Property, Information Technology and ECommerce Law 39, paras 1, 71-75.

60 Walter Eucken, Die Grundlagen der Nationalökonomie $\left(1947,9^{\text {th }}\right.$ edn, Springer 1989) 313; Claus-Wilhelm Canaris, 'Wandlungen des Schuldvertragsrechts - Tendenzen zu seiner "Materialisierung"' (2000) 200 Archiv für civilistische Praxis 273, 293.

61 Cf. Drexl (n. 12) paras 42-61.

62 Rolf H. Weber and Florent Thouvenin, 'Dateneigentum und Datenzugangsrechte - Bausteine der Informationsgesellschaft?’ (2018) 137 Revue de Droit Suisse 43, 70-72. 
tions of efficient data allocation driven by non-market forces. Therefore, even a FRAND licensing obligation should be considered with due caution as it should only be applied once the competitive process is really at stake and private autonomy jeopardised. ${ }^{63}$

\section{Industrial policy-driven market regulation and the principle of free market economy - a call for more market-driven innovation}

The abovementioned considerations unveil the underlying issue of which respective roles the EU and states should play in regulating the economy. One of the goals of the EU is to establish an internal market that is based on balanced economic growth and price stability and a highly competitive social market economy that promotes technological advancement and aims for a high level of protection and improvement of the quality of the environment, according to Article 3(3) TEU. Article 119(1) TFEU specifies that the EU and its Member States should achieve this in accordance with the principle of an open market economy with free competition. This - at least under a liberal reading - should guarantee a separation of powers between states and the economy. It should not only reduce the competences of the EU and the correlating abandonment of state sovereignty in the EU integration process but it should also limit the capability of Member States to pursue their own industrial policies by modelling and centrally planning their own economy detached from the requirement of competitive market processes. ${ }^{64}$ Indeed, it has to be noted that the principle of an open market system lacks normative strength and according to the CJEU consti-

63 In Microsoft, the General Court stated that 'the mere fact that the contested decision requires that the conditions to which any licences are subject be reasonable and non-discriminatory does not mean that Microsoft must impose the same conditions on every undertaking seeking such licence.' See Case T-201/04 Microsoft $v$. Commission [2007] ECR II-3602 = ECLI:EU:T:2007:289, para. 811. On the role of competition law as a safeguard of private autonomy and on advocating for an order-principled design of market rules and competition as a social institution see Franz Böhm, 'Freiheit und Ordnung in der Marktwirtschaft' (1971) ORDO 11, 20; Franz Böhm, 'Privatrechtsgesellschaft und Marktwirtschaft' (1966) ORDO 75, 140.

64 On the theory of economic constitution and the functionality of harmonisation in the internal market see Ernst-Joachim Mestmäcker, 'Soziale Marktwirtschaft und Europäisierung des Rechts' in Ernst-Joachim Mestmäcker (ed.), Wirtschaft und Verfassung in der Europäischen Union (Nomos 2003) 294. Peter-Christian Müller-Graff, 'Die wettbewerbsverfasste Marktwirtschaft als gemeineuropäisches 
tutes neither a justiciable right of individuals nor a general obligation of Member States to comply with that principle. ${ }^{65}$ Moreover, the EU treaties particularly with regard to the fundamental freedoms still give Member States a right to national limitations. Therefore, a mere liberal interpretation of this principle which does not take the social aspect of the market economy into account falls short of giving a conclusive answer to the question of what normative findings can be drawn from the open market economy principle. ${ }^{66}$ Yet it should be borne in mind that markets are constituted by the consent of economic citizens to individual transactions and typically do not require centralised coordination in the sense of a centrally planned economy. The legal foundation of markets consists in the freedom-of-contract principle, which is safeguarded by competition law. ${ }^{67}$ Decentralised decision making between the parties of the contract is to be favoured because individual economic preferences of numerous economic agents would be outvoted in a centralised decision-making process, and this would contradict the principles of individual freedom and self-determination, which are also enshrined in Articles 6, 16 and 17 CFR. ${ }^{68}$

Applying this principle of an open market and competition system to the question of how to regulate access to data one should note that the EU or states should refrain from directly innovation-enabling ex ante regu-

Verfassungsprinzip' in Peter-Christian Müller Graff and Eibe Riedel (eds), Gemeinsames Verfassungsrecht in der Europäischen Union (Nomos 1998) 53, 58.

65 Case 126/86 Giménez Zaera [1987] I-3697 = ECLI:EU:C:1987:395, para 10. The German Federal Constitutional Court further argued that the principle of free competition is only located within the operative part of the EU treaties and thus should not be the prevailing one, but can accordingly be balanced with other welfare goals of Member States. See German Constitutional Court, 30 June 2009, Cases 2 BvE 2/08 and others [2009] Entscheidungen des Bundesverfassungsgerichts 267, para. 396. Yet scholars argue that the economic constitutional dimension of this principle stems from the entrenchment of the market freedoms in the competition rules and the fact that it is clearly stated within Art. 3(2) TEU. See on this Ulrich Immenga and Ernst-Joachim Mestmäcker, 'Die Bedeutung der Wettbewerbsregeln in der Verfassung der EU' in Ulrich Immenga and ErnstJoachim Mestmäcker (eds), EU-Wettbewerbsrecht (C.H. Beck 2012) 1, 20.

66 See on this and competition law as part of the European Constitution, Josef Drexl, 'Competition Law as Part of the European Constitution' in Armin von Bogdandy and Jürgen Bast (eds), Principles of European Constitutional Law (Hart, C.H.Beck, Nomos 2010) 633, 642. Alfred Müller-Armack, 'Die Wirtschaftsordnungen sozial gesehen' (1948) ORDO 125.

67 Franz Böhm, Wirtschaftsverfassung und Staatsverfassung (Mohr Siebeck 1950) 5051; Böhm, 'Privatrechtsgesellschaft und Marktwirtschaft' (n. 63) 92.

68 See Drexl (n. 66) 660. It has to be noted that there are also direct market regulatory tools in the EU, e.g. agricultural policy. 
lation going beyond merely safeguarding the well-functioning of open competitive markets. Libertarian market considerations build their assumptions on the fact that under conditions of effective competition, rulebased economic freedoms of action lead to results that correspond to positive general welfare effects. ${ }^{69}$ One of the prerequisites of a competition system is thereby the primacy of exclusivity and imperfect knowledge that is usually constituted by a property system or factual exclusivity combined with contractual freedoms that are primary enablers of markets and that are again framed by regulation that safeguards the competitive process (freedom of competition) per se. ${ }^{70}$ Under these circumstances markets evolve spontaneously and usually regulate themselves. ${ }^{71}$ Competition is thereby an incentive for innovation and a means to discover new innovations. ${ }^{72}$ This still applies regardless of the introduction of the more economic approach and the new utilitarian and neo-classical welfare economics in the EU competition law framework in the early 2000s. Indeed, the static models that build on different efficiency criteria may define expected welfare outcomes and therefore may better detect individual welfare-reducing behaviour. ${ }^{73}$ This does not mean that the more economic approach simply renders the principle of an open market economy with free competition characterised by an evolutionary competitive process obsolete. ${ }^{74}$ Therefore, one should be cautious when directly regulating innovation-enabling open data access instead of only safeguarding competitive markets per se. Granting too broad access - similar to the public domain consideration in IP laws - may de facto destroy one of the prerequisites of markets and competition, namely the excludability of others. This in turn may not only en-

69 Ernst-Joachim Mestmäcker, 'Europäische Wirtschaftsverfassung' in (2009) Handwörterbuch des Europäischen Privatrechts Part 2 <hwb-eup2009.mpipriv.de/ index.php/Europäische_Wirtschaftsverfassung $>$ accessed 31 August 2020.

70 Eucken (n. 60) 256; Böhm, Wirtschaftsverfassung und Staatsverfassung (n. 67) 50.

71 Friedrich A. von Hayek, 'Der Wettbewerb als Entdeckungsverfahren' in Friedrich A. von Hayek (ed.) Freiburger Studien (Mohr Siebeck 1969) 249.

72 Ibid.

73 Mestmäcker (n. 56) 25, 39.

74 Cf. Viktor Vanberg, 'Consumer Welfare, 'Total Welfare and Economic Freedom On the Normative Foundations of Competition Policy' (2009) Freiburg Discussion Papers on Constitutional Economics 09/3 <www.econstor.eu/bitstream/1041 9/36471/1/617387532.pdf $>$ accessed 31 August 2020. 
danger the entire competitive process, it also may constitute a shift towards a more industrial policy-driven stance of direct market intervention. ${ }^{75}$

\section{Adverse effects of data sharing for consumer sovereignty, privacy and innovation}

Digitisation and the increasing use of big data combined with the widespread use of ML have led to new challenges that also affect information-specific power asymmetries between undertakings and consumers. In the privacy discussion of the digital economy regarding personal data, one of the most heatedly debated issues is whether consumers as users of internet-based services are capable of making rational and/or well-informed decisions about their data. This in turn has raised the legal issue of whether the contractual arrangements that are offered to them sufficiently protect consumers or whether markets suffer from a market failure due to information asymmetries and related behavioural issues of consumers, i.e. adverse selection and irrationality (or the so-called privacy paradox). ${ }^{76}$ Empirical research has shown that along with advancements that have made technologies more and more privacy intrusive, one can observe a growing number of people willing to reveal personal data. ${ }^{77}$ This has already led to

75 This is why in the latest phase of de-regulation of the telecommunication sector in 2003 and particularly from 2009 onwards, competition law has been juxtaposed to the EU's regulatory policy; cf. section B.I.2. above.

76 Applying Akerlof's example of market of lemons to data markets, the level of data protection as a value parameter of the offered service can only serve its purpose if the consumer understands what data protection really means. According to most recent empirical findings in relation to the economics of data, most consumers are aware of data protection but they simply do not care about their privacy anymore. This however leads to a market similar to those in Akerlof's example, namely one that does not make a higher quality service - meaning a service which offers a higher level of data protection - economically useful. This eventually leads to a market that only offers the minimum standard of data protection required. George A. Akerlof, 'The market for Lemons: Quality Uncertainty and the Market Mechanism' (1970) 84 Quarterly Journal of Economics 488. On the privacy paradox see Spyros Kokolakis, 'Privacy attitudes and privacy behaviour: A review of current research on the privacy paradox phenomenon' (2015) 64 Computers \& Society 122; Laura Brandimarte and Alessandro Acquisti, 'The Economics of Privacy' in Martin Peitz and Joel Waldfogel (eds) The Oxford Handbook of the Digital Economy (OUP 2012) 1, 14.

77 Daniel J. Solove, 'A Taxonomy of Privacy' (2006) 154 University of Pennsylvania Law Review 477. 
the introduction of the purpose limitation and transparency duties in the GDPR in order to better inform consumers about the purpose and conditions for future use of those data. Nevertheless, individuals may still be subject to bounded rationality and therefore end up not protecting their privacy. ${ }^{78}$ This issue of information asymmetries with regard to the use of data may be even more complex in times of AI.

The emergence of widespread use of ML has led to better insights into consumers' behaviours and preferences. Human experience as free raw material for translation into behavioural data thereby not only created enormous product or service improvements but also proprietary behavioural surplus, which, fed into ML applications, enabled predictions about consumers. ${ }^{79}$ This information resembles a digital reality, which is first of all detached from the traditional rational understanding of information by society and secondly is also detached from its traditional role within a sphere of social communication. Digital technologies led to a bifurcation and disassociation of information and communication. ${ }^{80}$ This has consequences for the role of communication in a digital age. Automated algorithmic information selection on the Internet governs a wide spectrum of individual action and creates statistical knowledge that is detached from a social reality. Entire business models and marketing strategies in e-commerce are now built on the creation of ML algorithms that govern or determine what information is found on the Internet ${ }^{81}$ produced ${ }^{82}$ considered relevant for each individual ${ }^{83}$ and chosen and/or consumed. ${ }^{84}$ Algorithmic selection essentially co-governs the evolution and use of the Internet by influencing the behaviour of individual producers and users, shaping the formation of preferences and decisions in the production and consumption of goods and services. ${ }^{85}$ This leads to a construction of reality, a kind of

78 Alessandro Acquisti, 'Nudging Privacy: The Behavioral Economics of Personal Information' in (2010) 7(6) IEEE Security and Privacy Magazine 82.

79 Shoshana Zuboff, The Age of Surveillance Capitalism - The Fight for a Human Future at the New Frontier of Power (Public Affairs 2019) 8.

80 Friedrich Kittler, Optische Medien ( $2^{\text {nd }}$ edn, Merve 2011) 26.

81 Search filtering and aggregation applications, e.g. what is indexed by search engines/crawlers.

82 Content production applications like algorithmic journalism.

83 Search and scoring applications; ranking.

84 Recommendation, scoring and allocation applications; both for economic and social choices - ranging from commercial goods to friends and partners.

85 Natascha Just and Michael Latzer, 'Governance by Algorithms: Reality Construction by Algorithmic Selection on the Internet' (2016) 39 Media, Culture \& Society 238 . 
governance marked by the targeted selection or omission of information, which eventually subconsciously shapes the consumers' behaviour.

This has led to the discussion of further introducing soft-paternalistic forms of data protection laws and direct market regulation of digital services in Europe, as under the current GDPR consent by the data subject makes any exploitative processing of data legally permissible and consumers still fail to value their privacy ${ }^{86}$ Moreover, the role of information intermediaries and their economic power is under particular scrutiny in the current platform regulation debate. ${ }^{87}$ Despite these effects, algorithmic governance ${ }^{88}$ may also have an impact on the innovation capacities within an algorithmic society. As already outlined above, applying the knowledge inferred from behavioural data of consumers always implies that individuals are categorised in different groups under which attention markets and the respective products and services are then 'individually' modulated. Despite great advantages that come with the use of ML in the Internet and ecommerce, it should also be considered whether it leaves the targeted consumer with enough possibility of alternative choices. Choice is usually safeguarded in efficient, competitive markets, as market forces that are driven by individuals' pursuit of self-interest lead to static and dynamic forms of competition. In this setting, markets typically generate an array of different products and services that reflect the need of the demand side. ${ }^{89}$ Yet algorithmic governance (or increasing widespread technological ad-

86 This is well-known under the so-called privacy paradox. Cf. Acquisti (n. 78) 8285; Frederik J. Zuiderveen Borgesius, 'Behavioural Sciences and the Regulation of Privacy in the Internet' in Alberto Alemanno and Anne-Lise Sibony (eds), Nudge and the Law: A European Perspective (Hart Publishing2015) 179; Christoph Krönke, 'Datenpaternalismus - Staatliche Interventionen im Online-Datenverkehr zwischen Privaten' (2016) 55 Der Staat 319.

87 Crémer and others (n. 5) 54-60.

88 Cf. Antoinette Rouvroy, 'Technology, virtuality and utopia: Governmentality in an age of autonomic computing' in Mireille Hildebrandt and Antoinette Rouvroy (eds), Law, Human Agency and Automatic Computing (Routledge 2011) 119, 13541; Marc Amstutz, 'Dateneigentum - Funktion und Form' (2018) 218 Archiv für civilistische Praxis 438, 445-551; Wolfgang Hoffmann-Riem, 'Verhaltenssteuerung durch Algorithmen - Eine Herausforderung für das Recht' (2017) Archiv des öffentlichen Rechts 1.

89 On the very notion of free markets and their forces see Adam Smith, An Inquiry into the Nature and Causes of the Wealth of Nations (University of Chicago Press 1976, first published 1776): 'By directing that industry in such a manner as its produce may be of greatest value, he intends only his own gain, and he is in this, as in many other cases, led by an invisible hand to promote and end which was no part of his intention.'. 
vancements) seems to reduce the various forms of demand in a pluralistic society. Personalisation stems from a mere prediction created by machines that analyse past behaviour. This however means that consumers are already bound by their personal past and potentially cannot simply make a new choice. Indeed, according to the ambiguity aversion and the Ellsberg paradox, humans generally tend to choose the known instead of the unknown..$^{90}$ This however, does not mean that humans should be deprived of other non-personalised product and service choices. Another factor to be borne in mind is that personalised services and products only resemble the categorical social stratification established by the ML analysis of the behavioural data and their categorisation. This may in the very end shape the society overall and may deteriorate a pluralistic one. Societal plurality in turn may be one of the sources of innovation. In the final analysis, technological advancement runs the risk of causing negative externalities where too wide access regimes for personal data have the potential to decrease consumer sovereignty and eventually innovation capacities of markets.

\section{Adverse effects of data sharing on competition and innovation}

Too broad data access regimes could also distort competition and may even have adverse effects on innovation in the long run. From a competition point of view, information embedded in data becomes relevant under two different considerations. First, data sharing may create too much market transparency, which could lead to anti-competitive (tacitly) collusive practices. ${ }^{91}$ Second, the information in data can also provide an advantage for undertakings that distorts competition. The combination of non-exclusively held information from several sources may provide certain already data-rich undertakings with additional knowledge that, due to data-specific economies of scope and scale, other competitors may not be able to reach. This may reduce both static and dynamic competition not only in markets where the digital conglomerates are already present but also across other markets. ${ }^{92}$

90 Jürgen Eichberger, David Kelsey and Burkhard C. Schipper, 'Ambiguity and social interaction' (2009) 61 Oxford Economic Papers 355.

91 See Ariel Ezrachi and Maurice E. Stucke, 'Sustainable and Unchallenged Algorithmic Tacit Collusion' (2020) 17 Northwestern Journal of Technology and Intellectual Property Law 218.

92 It has already been subjected to scrutiny in the EC merger control practice whether the concentration of control over valuable and (non-) replicable data re- 
As competition is defined as a discovery process ('Entdeckungsverfahren'), which builds on a certain degree of imperfect knowledge, high market transparency may simplify coordinated practices and eventually dismantle competition. The use of AI may enable the companies to gain such knowledge that facilitates coordinated practices. As algorithmic collusion also allows for unconscious parallelism, the coordination of market behaviours may even fall outside the scope of Article 101(1) TFEU. ${ }^{93}$ Indeed, the anticompetitive effect of broader data access regimes depends on many factors. In markets with more heterogeneous products and services where competition is not simply defined by price parameters real coordinated practices with anti-competitive effects are less likely ${ }^{94}$ The potential increase in market transparency makes a thorough assessment of potential adverse effects of the respective access regime necessary.

If market-dominant undertakings that are of paramount importance for competition across markets are also granted data access, this may give these dominant players such a competitive advantage that it may even render further data access regulation dysfunctional with regard to their innovation enabling function. AI is still predominantly used and developed by a handful of market-dominant companies. Although technological inclusion is already on the policy agenda of the EU and its Member States, particularly SMEs are lagging behind. Digital transformation requires high investment costs. Together with deterrence effects of the dominant incumbents, SMEs may have lesser incentives for further accessing and using data. ${ }^{95}$ Thus even though granting access to data does most likely increase the pos-

sources may create a significant impediment of efficient competition by either strengthening market power or leveraging their data advantages to other markets and thus create foreclosure concerns. See for example Apple/Shazam (Case M.8788) Commission decision of 6 September 2018 C(2018) 5748 final; Microsoft/ LinkedIn (Case M.8124) Commission decision of 6 December 2016 C(2016) 8404 final; Facebook/WhatsApp (Case M.7217) Commission decision of 3 October 2014 C(2014) 7239 final; Telefónica UK/Vodafone (Case M.6314) Commission decision of 4 September 2012 C(2012) 6063 final. Cf. Jörg Hoffmann and German Johannson, 'EU Merger Control and Big Data - On Data-specific Theories of Harm and Remedies' (2019) Max Planck Institute for Innovation and Competition Research Paper No. 19-05 9-29<https://papers.ssrn.com/sol3/papers.cfm?abstract_id=3364 $792>$ accessed 31 August 2020.

93 OECD, 'Algorithms and Collusion: Competition Policy in the Digital Age' (OECD 2017) 51.

94 Cf. Gencor/Lonrho (Case IV/M.619) Commission Decision of 24 April 1996 [1997] OJ L11/30, para. 141.

95 In its Communication on AI the European Commission already stated that it will facilitate access to AI of all potential users, especially small and medium-sized en- 
sibility for all firms to (theoretically) benefit from new data-driven innovation and AI technologies, the dominant incumbents may benefit disproportionately more. Data is one of the key components of AI applications. Enhanced data access will give them insights in consumer preferences that are relevant for succeeding in other market segments. Data access may thus strengthen the economic power of the dominant incumbents, which could have negative effects on static and dynamic competition in the long run.

Indeed, particularly in the case of digital conglomerates, undertakings often not only hold a dominant position on the individual platform or network market but they also have the resources and the strategic positioning to enable them to exert significant influence on the business activities of third parties or to expand their own business activities into ever new markets and sectors. This is also one of the reasons why markets of the digital economy already show strong and rapidly emerging concentration tendencies. Contrary to the expected market dynamism in digital platform markets, ${ }^{96}$ platform-specific network effects together with the data advantages and associated self-reinforcing effects have led to a tipping effect whereby the digital conglomerates seem to win entire markets. ${ }^{97}$ These circum-

terprises, companies from non-tech sectors and public administrations, to the latest technologies and encourage them to test AI as they are the ones simply not using it. See Communication from the Commission of 25 April 2018 to the European Parliament, the Council, the European Economic and Social Committee and the Committee of the Regions - 'Artificial Intelligence for Europe' $\operatorname{COM}(2018) 237$ final, 8.

96 The European Commission's merger practice has been built on the traditional error cost framework that favoured false negatives and seemed to be particularly relevant in the consumer communication sector. In the merger of Facebook/What$s A p p$ for instance, the Commission cleared the merger and stated that 'the consumer communications sector is a recent and fast growing sector which is characterised by frequent market entry and short innovation cycles [...]. In this market high market shares are not necessarily indicative of market power and, therefore, of lasting damage to competition.' Facebook/WhatsApp (Case COMP/M.7217) Commission decision of 3 October 2014 C(2014) 7239 final; para. 99. Latest studies show, however, that this was a wrong assumption and the predicted market disruptions have not occurred. There has been a general tendency towards less dynamism in platform markets and a higher likelihood of concentration tendencies in digital markets not only leading to static efficiencies but also creating dynamic costs. See Crémer and others (n. 5) 4; Jason Furman and others, 'Unlocking digital competition - Report of the Digital Competition Expert Panel' (2019) 4 $<$ https://assets.publishing.service.gov.uk/government/uploads/system/uploads/atta chment_data/file/785547/unlocking_digital_competition_furman_review_web.pd f $>$ accessed 31 August 2021.

97 Ibid. 
stances together with additional economies of scale and enormous resources of the incumbents have already led to strong market positions, which seem to cause both static and dynamic costs..$^{98}$ The increasing market concentration may also lead to a higher static productive efficiency, which could outweigh losses in both static allocative efficiency and dynamic efficiency, and thus no intervention in increasing concentration tendencies is needed. Yet it seems that high concentration in digital markets causes static costs as it may reduce effective prices for consumers, reduce choice or affect quality. ${ }^{99}$ Although most of the services may be free of charge, consumers in more dynamic markets might have given up less in terms of privacy or might have been paid for their data. ${ }^{100}$ Even beyond considerations specific to the platform market, it has become apparent that individual companies occupy central strategic positions with their products and services. Moreover, they create a wide range of dependencies on other market participants that allow the companies to distort the competitive process to their own advantage and to leverage their market power to other adjacent markets. ${ }^{101}$ Together with the creation of interrelated products and increased consumption synergies, this further increases switching costs for consumers and has led to the creation of so-called digital ecosystems. ${ }^{102}$ The digital ecosystem combined with a strategy of early elimination of potential rivals through start-up acquisition is not only consolidating the incumbents' strong market position but may also further increase entry barriers for rivals on the same or adjacent markets and segments - potentially even on market segments where the incumbent is currently not present. ${ }^{103}$ This in turn could then impede innovation as larger companies have less to fear from new entrants. Even if companies consider entering markets, many new entrants are not scaling up in the long run, as they simply cannot compete with the dominant market power of digital conglomerates and are thus already deterred from further investing in

98 Ibid.

99 Ibid.

100 Ibid.

101 Cf. Massimo Motta and Martin Peitz, 'Big Tech Mergers' (2020) Collaborative Research Center TR 224 Discussion Paper No. 147, 26-29, 30, 31-33, 34 $<$ www.crctr224.de/en/research-output/discussion-papers/discussion-papers\#DP14 $7>$ accessed 31 August 2020.

102 Ibid. 29, on the negative effects of one-stop-shopping and consumption synergies.

103 Ibid. 4-9. The issue of killer acquisitions or killer zones is the subject of current competition policy discussions. See e.g. Crémer (n. 5) 110. 
R\&D. ${ }^{104}$ This on the other hand leads to a reduction of further innovation incentives for market-dominant incumbents. ${ }^{105}$ This may render the role of innovation competition less relevant for succeeding in markets and thus may reduce both static and dynamic competition by non-contestable digital conglomerates.

This issue may be further amplified as the general rules on ex post abuse control under the current competition laws may fall short of adequately dealing with the increased risk of vertical and conglomerate exploitation of economic power. Even though the actual effects of such conduct may lead to market foreclosures (i.e. via platform envelopment ${ }^{106}$ ) if the changes that create these high market entry are merely structural in nature, they fall outside the scope of control. This led to the current debate about the future competition policy for both the EU and its Member States. Thereby the reconciliation of competition on the merits on the one hand and the goal of competition law to also protect the competition process as such, on the other, needs to be thoroughly assessed. In this context, the demarcation line between direct market regulation of digital conglomerates and a general competition law framework becomes increasingly blurred.

The current European legislative endeavours under the Digital Markets Act and the German legislature have already considered preventing digital

104 Carl Shapiro, 'Competition and Innovation: Did Arrow Hit the Bull's Eye?' in Josh Lerner and Scott Stern (eds), The Rate and Direction of Inventive Activity (University of Chicago Press 2011) 361, 364.

105 Cf. Arrow (n. 18) 620. Put differently, the secure monopolist's incentive to achieve a process innovation is less than that of a competitive firm because the monopolist with lower costs will merely replace itself, while the competitive firm will (by assumption) take over the market, in which it previously earned no economic profits. See also on the 'replacement effect' Jean Tirole, The Theory of Industrial Organization (MIT Press1988) 392-98.

106 Platform envelopment is a common and widespread phenomenon with significant implications for the evolution of platform and intermediation markets. Envelopment entails entry by one platform provider into another's market by bundling its own platform's functionality with that of the target so as to leverage shared user relationships and common components. Dominant firms, which are otherwise sheltered from entry by stand-alone rivals due to network effects and high switching costs, can be vulnerable to an adjacent platform provider's envelopment attack and this can eventually lead to a market tipping for the platform. See on this Thomas Eisenmann, Geoffrey Parker and Marshall Van Alstyne, 'Platform Envelopment' (2011) 32 Strategic Management Journal 1270, 1271. For an example in the retail banking and payments sector see Miguel de la Mano and Jorge Padilla, 'Big Tech Banking' (2018) 14 Journal of Competition Law \& Economics 494, 504-506. 
conglomerates from using their foreclosing strategies so as to ultimately safeguard other companies' ability to compete for market shares and customers by competitive means. ${ }^{107}$ This led to the call for specific restrictions on certain conducts of digital conglomerates that are typically used to further consolidate their ecosystems across markets. ${ }^{108}$ Along this line, the $10^{\text {th }}$ amendment of the German Act Against Restraints of Competition (GWB) entails a pro-active preventive control regime for undertakings of paramount importance for competition across markets.

Art. 19a GWB establishes a three-step control regime that first of all gives the German Federal Cartel Office (BKartA) the power to ascertain an undertaking's superior economic power ${ }^{109}$ and its particular relevance for competition across markets. Once such a position is ascertained, these undertakings are subject to the special obligations to refrain from certain conduct. ${ }^{110}$ Ultimately the laws provide for an efficiency justification where the burden of proof lies with the undertakings. The laws further set out the obligation to refrain from creating or consolidating further entry barriers with regard to data. ${ }^{111}$ Here the role of data access rights becomes particularly relevant as the official grounds of the law explicitly refer to 'digital conglomerates' further data access sources as one of the reasons for further foreclosure scenarios. ${ }^{112}$

This is exactly where another tension between data access and exclusivity arises. A too broad access regime could eventually favour dominant in-

107 See Crémer and others (n. 5) and Report of the German Wettbewerbskommission 4.0, 'Ein neuer Wettbewerbsrahmen für die Digitalwirtschaft' (2019) paras 9-11 <www.bmwi.de/Redaktion/DE/Publikationen/Wirtschaft/bericht-der-kom mission-wettbewerbsrecht-4-0.pdf?__blob=publicationFile $\& v=12>$ accessed 31 August 2020.

108 Ibid.

109 Which goes beyond the traditional dominant market power assessment.

110 Sec. 19a(2) GWB-new. Gesetz zur Änderung des Gesetzes gegen Wettbewerbsbeschränkungen für ein fokussiertes, proaktives und digitales Wettbewerbsrecht 4.0 und anderer Bestimmung (GWB-Digitalisierungsgesetz) Gesetz von 01.01.2021 - Bundesgesetzblatt Teil I 2021 Nr. 1 von 18 Januar 2021. Cf. Gesetzentwurf der Bundesregierung - Entwurf eines Gesetzes zur Änderung des Gesetzes gegen Wettbewerbsbeschränkungen für ein fokussiertes, proaktives und digitales Wettbewerbsrecht 4.0 und anderer wettbewerbsrechtlicher Bestimmungen (GWB-Digitalisierungsgesetz) (9 September 2020) $15<$ www.bmwi.de/R edaktion/DE/Downloads/Gesetz/gesetzentwurf-gwb-digitalisierungsgesetz.pdf? blob=publicationFile\&v=6> accessed 15 September 2020 .

111 Sec. 19a(2) No. 3 (ibid.).

112 Bill of the Federal Government on the 10th amendment of the German Act Against Restraints on Competition (GWB) (n. 111) 84. 
cumbents and may fall short of maintaining competition in the long run. It is crucial that the long-term effects of such access regimes are thoroughly considered. Accordingly, one can think of three potential ways forward. The first is the implementation of a competition control regime as already outlined above that potentially bars digital conglomerates from access. In this case, however, the conflict between the envisaged access regimes and the control regime of digital conglomerates needs to be resolved. To this end, the general competition law control regime needs to be applicable in sector-specific access regimes and needs to prevail. Moreover, the administrative responsibilities and collaboration between the NCAs and the specific supervisory agencies need to be adjusted. The second option would be to formulate asymmetric sector-specific access rights that bar already data-rich incumbents from relying on the access rights unless they can prove efficiency. This solution may also depend on the adjustment of the relationship between horizontal and sector-specific access regimes and may make the balancing of different regulatory goals necessary. The third option would entail an asymmetric reciprocity clause that makes the reciprocal sharing of data mandatory. ${ }^{113}$

\section{Evaluation of the data access regimes for digital payment services}

The access regimes enshrined in the PSD2 relate to both the public interest of further increasing competition and innovation in the payments market and the private interests of customers to make use of certain innovative payment services. This is important when assessing to what extent the sector-specific access regimes of the PSD2 considered the regulatory principles for enhancing data-driven innovation outlined above. This may not only make both a public and/or private law regulatory approach possible, it also may cause certain tensions when a right of the payment service user to make use of certain innovative payment services - enshrined in contract laws - is contradictory to a necessary data governance approach that safeguards innovation. This contribution outlines that private interests need to be duly reconciled with the public interest of safeguarding competition and thus innovation in the payments markets. This will ultimately increase consumer welfare and thus better benefit the customers in the long run.

113 Fabiana Di Porto and Gustavo Ghidini, 'I access your data, you access mine: Requiring data reciprocity in payment services' (2020) 51 International Review of Intellectual Property and Competition Law 307, 319-27. 
There are two different innovation capacities in the payments sector. Increasing innovation in financial technology (FinTech) or payments technology (PayTech) and the evolution of retail banking prompted by Open Banking.

As one of the key concepts of new digital business models builds upon customer-centricity that is particularly demand side-driven by the generation of millennials, the role of market forces to foster demand side-driven innovation seems to already serve as an incentive for traditional incumbents to further innovate. ${ }^{114} \mathrm{~A}$ look at the global FinTech investments as early as 2015 and the FinTech-specific IPOs, with companies such as PayPal, Square, WorldPay and First Data achieving multi-billion-dollar market capitalisations - larger than many traditional incumbent financial institutions, seems to support this assumption. Therefore the question inevitably arising is what role the legislature should (have) play(ed) in further accelerating the surge of FinTech companies in the increasingly data and technology-driven payments markets. ${ }^{115}$ In the US, for example, the legislature abstained from direct innovation-enabling regulation and focused its regulatory interventions on specific consumer protection laws and financial supervisory laws. ${ }^{116}$ In Europe, however, the disruptive market penetration of (independent) FinTech providers and the FinTech innovation capabilities of incumbents traditionally seemed to lag behind the global trends, particularly those in the US. ${ }^{117}$ This led to a more industrial policy-driven, innovation-enabling regulatory approach in the EU that

114 Alex Lipton, David Shier and Alex Pentland, 'Digital Banking Manifesto: The end of banks?' (MIT 2016) 6 <www.getsmarter.com/blog/wp-content/uploads/20 17/07/mit_digital_bank_manifesto_report.pdf $>$ accessed 31 August 2020; PwC, 'Blurred Lines: How FinTech is shaping financial services - Global Fintech Report' (2016) $8<$ www.pwc.de/de/newsletter/finanzdienstleistung/assets/insuranceinside-ausgabe-4-maerz-2016.pdf $>$ accessed 31 August 2020. Though see for the issue of consumer inertia Amelia Fletcher, 'Disclosure as a tool for enhancing consumer engagement and competition' (2019) Behavioural Public Policy 4.

115 Accenture, 'Fintech and the evolving landscape: landing points for the industry (2016) 3 <www.accenture.com/t20161011T031409Z_w_/pl-en/_acnmedia/PDF-1 5/Accenture-Fintech-Evolving_landscape.pdf > accessed 31 August 2020.

116 Cf. Diana Milanesi, 'A new banking paradigm: the state of open banking in Europe, the United Kingdom and the United States' (2017) TTLF Working Paper No. 29, 26-30 <https://law.stanford.edu/publications/a-new-banking-paradigm-t he-state-of-open-banking-in-europe-the-united-kingdom-and-the-united-states/> accessed 31 August 2020.

117 Gregor Dorfleitner and Lars Hornuf, 'Neue digitale Akteure und ihre Rolle in der Finanzwirtschaft - Eine Analyse des deutschen Marktes unter besonderer Berücksichtigung von Datenschutzaspekten' (abida 2018) $8<$ www.abida.de/sites 
should create more competition in a market with concentrations tendencies.

By introducing asymmetric regulation, the potential un-contestable competition advantages of already existent incumbents should be offset. By reducing the high regulatory entry barriers with a special licence for third-party payment providers (TPPs) and by introducing the access-to-account rules - strengthening consumer engagement by directly outlining the rights of payment services users and indirectly of TPPs - should force incumbents to enable data-driven FinTech services. The laws enshrined in the PSD2 aim to provide not only a level playing field in the payments market but also directly spur innovation. ${ }^{118}$ The question remains, however, whether the PSD2 is not putting traditional incumbents at such a disadvantage that it will diminish innovation incentives and unduly infringe their right of freely conducting a business. This again leads back to the very question of whether a market failure existed and whether ex ante market regulation or a more flexible competition law solution would have been the right response for tackling foreclosure scenarios by factual (data) exclusivities in the payments market.

\section{Payment initiation services}

\section{Overview}

With regard to new front-end payment services or products, payment initiation services (PISs) proved to be efficient, not only reducing transaction costs for consumers but also enabling e-commerce for consumers without payment cards or other digital forms of payment. ${ }^{119}$ PIS providers (PISPs) are FinTech companies that offer low-cost solutions for consumers to pay instantly for their online transactions. These online services enter a user's payment account to initiate the transfer of funds between the user's account and the merchant's account with the user's consent, and inform the merchant once the transaction has been initiated and funds are on their way. This is done by establishing a software bridge between the website of the merchant and the online banking platform of the payer's account at

/default/files/Gutachten_ABIDA_Neue_Digitale_Akteure_Finanzwirtschaft.pdf accessed 31 August 2020.

118 Emphasis added by the author. See Recitals 4, 33 PSD2 (n. 10).

119 See Recital 27 PSD2 (n. 10). 
the account servicing payment service provider (ASPSP) via application programming interfaces (APIs). What is crucial to note is that access to the user's payment account, and thus typically cooperation between ASPSPs and the PISP, is needed.

At this point, the PSD2 sets out the obligation for ASPSPs to grant access by executing payment orders initiated through PISPs on the condition that the customer has given explicit consent and that the account is accessible online. ${ }^{120}$ Such obligation does not depend on any existing contractual relationship between the ASPSPs and the PISPs and is not dependent on typical competition law thresholds. Moreover, ASPSPs must treat all the payment orders transmitted through the services of a PISP 'without any discrimination other than for objective reasons, in particular in terms of timing, priority or charges vis-à-vis payment orders transmitted directly by the payer'. ${ }^{121}$ Accordingly, the intermediation service conducted by PISPs should not be dealt with differently with regard to charges for directly transmitted payment orders. Indeed, this means that unless there are any objective reasons, no additional charges should be collected from the accounts holder. ${ }^{122}$ Therefore, the PIS is not free stricto sensu, but it is only part of the fixed amount that is already regularly charged by the bank vis-àvis the account holder. ${ }^{123}$ Nevertheless the legal wording is unclear with regard to whether banks can charge an additional fee from the PISPs. 'Without any discrimination vis-à-vis payment orders transmitted directly by the payer' could be interpreted in two ways - no additional charges at all or merely no additional charges vis-à-vis the customers. The wording only refers to the legal relationship between the customer and the ASPSP. It does not refer to any legal relationship between an intermediary and the ASPSPs. From a legal systematic and dogmatic point of view, the implementation of the access obligation in private or public laws may further clarify this point.

In a first line of thought, - within a private law solution - the non-discriminatory access obligation that defines the scope of duties under the framework contract between banks and their customers may also define the obligations of the ASPSs in relation to the PISPs. This obligation is

120 Arts 66(1), (4), 64(1) PSD2 (n. 10).

121 Art. 66(4) lit. c) PSD2 (n. 10).

122 Art. 66(4) lit. c) PSD2 (n. 10).

123 See Dutch Authority for Consumers \& Markets, 'Fintechs in the payment system: the risk of foreclosure - Report' (2017) $35<$ www.acm.nl/sites/default/files/d ocuments/2018-02/acm-study-fintechs-in-the-market-the-risk-of-foreclosure.pdf $>$ accessed 31 August 2020. 
bonam partem and thus it would still be in line with privity-of-contract principle. The same modalities as for payment orders transmitted directly by the account holder should apply, which means that the ASPSPs should grant access to PISPs without additional charges, unless objectively justified.

The second interpretation - under a public law approach - resembles a traditional compulsory licence obligation known in refusal-to-deal cases. This would restrict the non-discrimination obligation to the fee scheme between bank and costumers, without having any effect on the legal relationship between ASPSPs and PISPs. Accordingly, the PSD2 ${ }^{124}$ may be implemented by merely setting out an obligation to enter into a licensing contract and the modalities of access could be freely negotiated within the general limitations of excessive pricing under antitrust laws and the data governance provisions - laid down in the financial supervisory laws - applicable in this context. Yet, it has to be noted that the PSD2 does not explicitly set out a right for PISPs. Article 36 PSD2, which outlines a POND (proportionate, objective and non-discriminatory) access regime to payment account services of credit institutes, does not refer to the opening up of account interfaces in PIS cases.

Although not explicitly addressing the legal relationship between the ASPSP and the PISP, the current scholarly debate puts forth arguments for both interpretations. ${ }^{125}$ Looking at the implementation of the PSD2, the German legislature implemented the access obligations outlined in the PSD2 in both private and public laws. It outlined the right of the customer (consumer and merchant) to make use of PIS within Germany's special law of obligations pertaining to payment services without the need for ASPSPs and PISPs to enter into a contract. ${ }^{126}$ The legislature further out-

124 Art. 66(1) PSD2 (n. 10).

125 See Giuseppe Colangelo and Oscar Borgogno, 'Data, Innovation and Transatlantic Competition in Finance: The Case of the Access to Account Rule' (2019) European Union Law Working Papers No. 35, 16-17 < https://papers.ssrn.com/so 13/papers.cfm?abstract_id=3251584 $>$ accessed 31 August 2020; Inge Graef, Martin Husovec and Jasper van den Boom, 'Spill-overs in data governance: the relationship between the GDPR's right to data portability and EU sector-specific data access regimes' (2020) 9(1) Journal of European Consumer and Market Law 3, 12; de la Mano and Padilla (n. 106) 504; Di Porto and Ghidini (n. 113). Colangelo and Borgogno as well as Graef, Husovec and van den Boom argue in favour of possible charges for TPPs. Di Porto and Ghidini as well as de la Mano and Padilla interpret the access provisions as granting free access for TPPs and criticise the lack of remuneration for incumbent banks.

126 Sec. $675 \mathrm{f}(3)$ German Civil Code (BGB). 
lines the duties of ASPSPs and PSPs in the Payments Services Supervision Act, which then refers to the Delegated Regulation concerning Regulatory Technical Standards (RTS Delegated Regulation) that orders the opening up of account interfaces. ${ }^{127}$ By implementing the obligations of the different parties involved into both public and private statutory laws, the legislature fails to provide a coherent solution that sufficiently addresses the legal relationship between the ASPSP and PISP. The questions whether the PISP has a right vis-á-vis the ASPSs or whether remuneration can be granted for ASPSPs by the TPPs remain unclear and need further clarification. Yet it should be kept in mind that remuneration should be possible in order to safeguard innovation incentives for incumbent banks.

\section{Non-market-driven FinTech innovation regulation and structural disadvantages of incumbent banks}

Against the backdrop of the role of data exclusivity for incentivising undertakings to further invest in data-driven innovation it firstly has to be acknowledged that payment initiation services build on access to data on two different grounds. First, the PISP needs the information whether the credit transfer has been successfully conducted. Second, this information has to be transmitted in real time, as instant processing of the payment services is one of the key innovation parameters of the offered services. In this sense PIS constitutes a rather technology-driven innovation that needs only a very limited amount of data. The data are essential for the PISPs though, as without immediate confirmation of the credit transfer the ecommerce sale transaction cannot be conducted quickly.

With regard to the investments made, it is not the production or analysis of data but rather the transmission of data that is costly, as the PSD2 together with the RTS Delegated Regulation provide for a data governance regime that should guarantee secure communication via access interfaces. ${ }^{128}$ This requires additional investment in in-house IT-infrastructure

127 See Secs 48, 49 German Payment Services Supervision Act (Zablungsdiensteaufsichtsgesetz, ZAG), Art. 36 Commission Delegated Regulation (EU) 2018/389 of 27 November 2017 supplementing Directive (EU) 2015/2366 of the European Parliament and of the Council with regard to regulatory technical standards for strong customer authentication and common and secure open standards of communication [2017] OJ L69/23 (RTS Delegated Regulation).

128 In this context, application programming interfaces (APIs) have been deemed the most reliable and tested technology to facilitate secure and reliable access to 
and/or demands closer cooperation with financial technology developers, which eventually may even change the entire value chains of the incumbents. ${ }^{129}$ Moreover, the new regulatory framework on payment systems also creates certain risks, which cause costs that traditional banks as incumbents have to address unilaterally. This includes increased operational risk, due to the necessity to allow access to customer payment account (information) and the threat of losing the direct customer interaction on the front end. Incumbent banks will therefore potentially end up as deposit holders for customers ('dump pipes') as they may lose the possibility to fully capture the margins that stem from value-added services within direct customer relations. ${ }^{130}$ There are also increased ICT-related, data protection, security and fraud risks as data are shared with third parties, which - although authentication is needed - cannot be freely chosen by banks anymore. The risks stemming from TPPs therefore have to be borne mainly unilaterally by the incumbent banks. ${ }^{131}$ These aspects place the banks at an additional disadvantage relative to the TPPs, which are freed from most of the risk and compliance considerations mentioned above and are thus freeriding on the expenses of market incumbents. Moreover, they also do not need to bear the minimum cost of a regulated entity in terms of compliance and capital requirements. Asymmetric regulation with regard to financial supervisory laws further enables the entry of PISPs by establishing a special licence and thus leaves the market incumbents with higher operational costs. This becomes particularly relevant in light of the fact that the PISPs offer a functionally equivalent service that renders the bank and the PISPs competitors aiming for the direct customer relationship and operat-

customers' accounts, even though the technology is not directly mentioned in the directive or the RTS Delegated Regulation. See also Marcos Zachariadis and Pinar Ozcan, 'The API economy and digital transformation in financial services: the case of open banking' (2016) SWIFT Institute Working Paper No. 2016-001, $4<$ https://papers.ssrn.com/sol3/papers.cfm?abstract_id=2975199> accessed 31 August 2020.

129 Ibid. 15.

130 See Simonetta Vezzoso, 'Fintech, access to data, and the role of competition policy' in Vicente Bagnoli (ed.) Competition and Innovation (Scortecci 2018) 35.

131 See on the risks of Open Banking and the mitigating measures enshrined in the PSD2, Brad Carr, Pablo Urbiola and Adrian Delle-Case, 'Liability and Consumer Protection in Open Banking' (Institute of International Finance 2018) $5<$ www.ii f.com/portals/0/Files/private/32370132_liability_and_consumer_protection_in_o pen_banking_091818.pdf> accessed 31 August 2020. 
ing on the same market - and not on another (after) market. ${ }^{132}$ As the choice to include this asymmetric access regulation in the PSD2 also enables digital conglomerates to enter the market, this puts the market incumbents at a further competitive disadvantage. As outlined above, digital conglomerates have established ecosystems on which to build their businesses. Together with their data superiority, they may end up re-shaping traditional retail banking and payment markets with the risk of further monopolisation in the long run. ${ }^{133}$ This in turn would negatively affect one of the regulatory goals of the PSD2, namely the spurring of further innovation to create more competition and thus more financial stability.

The access regulation for PIS deviates from the economic criteria outlined above, whereby welfare-enhancing effects should be achieved through more exclusivity, rather than through open access as the default rule. Although the retail banking and payment sector has always been characterised by lock-in problems, a low elasticity of demand and a general lack of competition, it should also be considered that in the payments market, there have been disruptions despite the lack of access to the customers' accounts. Distributed ledger technology led early on to the creation of virtual currencies, and as already outlined above, other payment providers such as PayPal, Wirecard, Venmo and Klarna were also already existent in the payments markets in Europe before the PSD2 entered into force. ${ }^{134}$ Thus it is questionable whether the market really failed due to a lack of competition or whether the reasons for less successful implementation of FinTech services in the European payments markets rather stem from a lack of demand, i.e. the unwillingness of consumers to share their data and to use new payment technologies. ${ }^{135}$ In the latter case however, ordering

132 This ultimately depends on the relevant market definition. It seems that customers do not make any difference between third-party payment providers and other means of payment and thus are both operating on the same relevant market.

133 De la Mano and Padilla (n. 106), Eisenmann, Parker and Van Alstyne (n. 106).

$134 \mathrm{PwC}$ (n. 114) 12; Joint Committee of the European Supervisory Authorities, 'Joint Committee Discussion Paper on the Use of Big Data by Financial Institutions' (2016) 6 <www.esma.europa.eu/system/files_force/library/jc-2016-86_discu ssion_paper_big_data.pdf?download=1> accessed 31 August 2020; Emilios Avgouleas, 'Regulating Financial Innovation' in Niamh Moloney, Eilis Ferran and Jennifer Payne (eds), The Oxford Handbook on Financial Regulation (OUP 2015) 610.

135 In already existing private initiatives, consumers have shown reluctance to share their data with third parties due to concerns about security and privacy as well as 
further data access rights might still not efficiently remedy the informational and behavioural market failure of consumer inertia.

From a legal competition policy perspective, it is also questionable whether a denial of access for PIS would have met the legal requirements of Article 102 lit. b) TFEU and the exceptional circumstances test outlined by the CJEU in refusal-to-deal cases. There has been already considerable competition within the retail banking market that makes both exploitative abuse and exclusionary abuse of market dominance under essential facility considerations unlikely. Indeed the terms and conditions regarding the opening up of bank accounts were standards already set by the bank incumbents and the lack of consumer engagement may have led to a lack of choice on exactly this service attribute. Yet, TPPs were already present in the market and there were other means of payment without having access to the customer's account. These competition-specific considerations build on market dominance, which depends on the vague concept of the relevant market and indeed could be assessed differently. Nonetheless, it is doubtful whether denying third parties access to the customers' bank accounts was indispensable, whether it actually illegally excluded other competitors and thus constituted an exclusionary abuse, and whether this in fact caused harm to competition and limited innovation. Unlike the Microsoft case, where Microsoft's exclusionary conduct and incontestable dominant market power justified the sharing of interoperability information in order to disseminate a technical standard that enables interoperability as well as competition and innovation, the case in payments markets is different. Payment services are highly regulated. This may confine market force-driven efficiencies. Price competition in relation to the already existent payment methods is limited, as rules on pricing schemes of other means of payment exist. ${ }^{136}$ Also with regard to other modalities of the payment services that could be positively influenced by competition in

uncertainty and a lack of trust. See Optimisa, 'Informing the development of communication tools designed to increase consideration of switching among PCA and SME customers - Research Report prepared for the Competition and Markets Authority' (2016) < https://assets.publishing.service.gov.uk/media/56dd7 10ded915d0376000008/Qualitative_report_of_findings_prepared_by_Optimisa.p df $>$ accessed: 31 August 2020.

136 See for example Regulation (EU) 751/2015 of the European Parliament and of the Council of 29 April 2015 on interchange fees for card-based payment transactions [2015] OJ L123/1 or further regulation in the PSD2, which established a maximum multilateral interchange fee level per card transaction and banned retailers from imposing surcharges on customers for the use of these types of cards. Also, Art. 62 PSD2 regulates the fee scheme. 
the payments market, the PSD, the PSD2, the RTS Delegated Regulation and other payments regulations set a high level of data governance rules under which data protection, data security and both syntactic ${ }^{137}$ and semantic interoperability ${ }^{138}$ should be established. Under these circumstances, an even more competitive market brought about by enabling entry to PISPs might not have necessarily led to the creation of better or more innovative services and thus more static and dynamic efficiencies. This holds particularly true as incumbent banks were already streamlining value-added solutions by incorporating (open) APIs and collaborating with FinTech providers. ${ }^{139}$ This - ipso facto - also casts doubt upon the causality of a lack of universal entry of PISPs to all bank accounts of customers and less innovation capacities in the payments market. It is further important to notice that the purpose limitation embodied in the PIS access regime already further limits innovation that goes beyond the provision of PIS. Thus, it is the legislature that not only defines how the innovative payment service should look, it further orders their universal dissemination in the markets.

On the other hand, it is arguable whether the universal access regime may negatively influence innovation of payment services in the long run as incentives for incumbent banks to invest and innovate are reduced. As the regulatory framework pertaining to PIS creates a data governance frame-

137 Here it has to be noted that the new RTS Delegated Regulation (n. 127) does not entirely standardise the transmission of data via interfaces. Both APIs and direct customer interfaces (i.e. Homebanking Computer Interface (HBCI), or Financial Transaction Services (FinTS)) are still allowed in order to maintain technical neutrality. The Euro Retail Payments Board, SWIFT and the API evaluation group are currently working on standardised 'plug and play' APIs and standardised forms of communication under the SWIFT ISO 20022 standard. Yet, there are still private, proprietary APIs within the 4000 retail banks that cause enormous practical impediments and different data models used that do not fully offer full interoperability. See on this Clemens Jestaedt, 'Kontoinformationsdienste - neue Online-Services unter Regulierung' (2018) Zeitschrift für Banken- und Kapitalmarktrecht 445, 447; Zachariadis and Ozcan (n. 128) 6.

138 With regard to the question of sufficient funds, Art.36(1) lit. c) RTS Delegated Regulation (n. 127), and with regard to personal credentials, the IBAN rules already standardise semantic interoperability under Art.5(1) lit.a) Regulation (EU) No. 260/2012 of the European Parliament and of the Council of 14 March 2012 establishing technical and business requirements for credit transfers and direct debits in euro and amending Regulation (EC) No. 924/2009 [2012] OJ L 94/22 (SEPA Regulation).

$139 \mathrm{PwC}$ (n. 114) 10. 
work, which ambition is to already establish high-quality services, ${ }^{140}$ the potential negative effects of overly broad access regimes seem to be outweighed at first sight. Yet it has to be noted that there is still no de facto standard with regard to communication in the payments sector. ${ }^{141}$ Moreover, the widely used SWIFT ISO 20022 standard does not fully offer (semantic) interoperability and a higher degree of data granularity that is needed for efficient use of ML. ${ }^{142}$ Moreover, the entrance of digital conglomerates certainly creates strong incentives for incumbent banks to further invest and build value-added solutions for customers. Nevertheless, incumbent banks might fail to build up their own ecosystems, which would be ultimately necessary to compete with the digital conglomerates. ${ }^{143}$ Thus, from both the perspective of maintaining the competition process per se and Article $16 \mathrm{CFR}$, it is questionable whether such a regime may eventually safeguard competition in the payments market in the long run and whether it really appropriately confines the incumbent banks' right to freely conduct a business.

Thus it would have been advisable to apply a more competition-centric approach that would align both the public interest in spurring innovation and private interests involved. Instead, it must be acknowledged that the PIS regulation still seems to be yet another industrial policy-driven attempt

140 The goal of interoperable communication solutions that should be achieved by following communication standards of international or European standardisation organisations is one example. Cf. Art. 30(3) and Recitals 21, 22 RTS Delegated Regulation (n. 127). The SWIFT ISO 20022 standard for instance already establishes a certain granularity of data by defining data model and communication standards in order to harmonise communication in the international finance and payments sectors. The same applies to private standardisation endeavours with regard to APIs. Cf. SWIFT, 'SWIFT ISO 20022 Migration Study - Consultation Paper' (2018) <https://buyerscredit.files.wordpress.com/2019/04/swift_s tandards_iso20022_migration_study_consultation_paper.pdf $>$ accessed 31 August 2020; Berlin Group, 'Joint Initiative on a PSD2 Compliant XS2A Interface - Next GenPSD2 XS2A Framework, Operational Rules Version 1.3' (21 December 2018) <https://77cb457b-3353-4bdc-8ab6-ff6bb2ccdc98.filesusr.com/ugd/ c2914b_2cf4db130e4d4aa9a5547acd342865e2.pdf $>$ accessed 31 August 2020.

141 There are multiple communication standards in the payments sector that are still not interoperable, e.g. EDIFACT, IFX, OAGi, TWIST. Cf. Bankenverband, 'ISO 20022 im Überblick' <https://bankenverband.de/media/files/ISO-20022_imueberblick.pdf $>$ accessed 31 August 2020.

142 Cf. 'ISO 20022 White paper', 5 <www.iso20022.de/white-paper/> accessed 31 August 2020); SWIFT (n. 140) 23. There is no possibility of bijective display of information once different standards are used, i.e. MX-to-MT conversions do not work properly.

143 Cf. de la Mano and Padilla (n. 106) 504-505; Di Porto and Ghidini (n. 113) 9. 
to directly shape innovation ${ }^{144}$ instead of merely safeguarding competition, which would have led to market force-driven innovation that not only responded to the sovereign will of market actors but also guaranteed more innovation in the long run.

This observation is attenuated when one broadens the regulatory perspective and looks at the role of consumers' data sovereignty, which led the legislature to introduce a data portability regime in Article 20(2), (1) GDPR. The same considerations may also justify a broader access regime in PIS cases. The horizontally applicable data portability regime set out in Article 20(2), (1) GDPR for instance has a Janus-faced character, being set in between competition law and data protection law. Particularly data protection-specific considerations give rise to an interpretation of the data portability right as a right to information, which has to be granted for free - as long as such right is not abusively used by the data subject. ${ }^{145}$ Such interpretation does not resemble an ownership-like right of the data subject. It rather strengthens the sovereignty of the data subject by merely strengthening control over the personal data and tackling data lock-ins. ${ }^{146}$ However, in contrast to the GDPR, the PSD2 does not refer to data subjects' right of data portability in order to strengthen their control over personal data. The wording simply refers to a right of the consumer to make use of a specific third-party payment service - which was already possible in some cases prior to the PSD2 but not valued by customers. ${ }^{147}$ The remedial function of the access-to-account rule and the data portabili-

144 This also led to the creation of FinTech-specific innovation hubs and regulatory sandboxes. For an overview of the regulatory endeavours to further boost innovation in FinTech in the UK and the EU see Milanesi (n. 116) 23.

145 Art. 12(5) GDPR.

146 See Recital 68 of the GDPR. In this line of interpretation of the data portability regime see Kai von Lewinski, in Heinrich Wolff and Stefan Brink (eds) Beck'scher Online-Kommentar Datenschutz-Grundverordnung (2020) Art. 20 para 7. Data protection law is also one of the core determinants of further data-driven business models that depend on the portability of data in order to avoid data-induced lock-ins that may have negative effect on competition. Therefore, the right of data portability also remedies a market failure that stems from competition specific considerations. See on this Heike Schweitzer and Martin Peitz, 'Datenmärkte in der digitalisierten Wirtschaft: Funktionsdefizite und Regelungsbedarf?' (2017) ZEW Discussion Paper No. 17-043, 45 <http://ftp.zew.de/pub/zew-docs/dp/dp17 043.pdf $>$ accessed 31 August 2020.

147 See the wording of Art. 66(1) and the correlating Recitals 29-32 PSD2 (n. 10). Contrary to Recital 68 of the GDPR where the legislature explicitly refers to the data portability right in order to ensure consumers' data sovereignty, the PSD2 is more neutral and solely addresses the need for harmonising regulation, filling 
ty regime under Article 20(2), (1) GDPR are different. Although both in fact tackle consumer lock-ins, the lock-in addressed under the PSD2 accessto-account rule does not stem from a privacy law-induced market failure, as the portability regime under Article 20 GDPR does. ${ }^{148}$ It is not only the personal information held by the ASPSs that is needed in order to make use of PIS. The decision of the BKartA pertaining to the general terms and conditions used by some retail banks that banned the use of personal security credentials (PIN and TAN) on e-commerce platforms in order to make use of certain PIS also shows this. Here, the BKartA held that this constituted inter alia a breach of Article 101(1) TFEU. The chosen terms and conditions were not essential for establishing a coherent security and data protection concept for their offered services. According to the BKartA these retail banks rather tried to foreclose other innovative market entrants offering payment initiation services by introducing this duty with a correlating exemption from liability where PISs were used. ${ }^{149}$ Moreover, as already outlined above it is the real-time direct access to the account that is needed in order to effectively enable PIS, and not further usage of personal information provided by the retail banks, which could just as well have been brought before the court under the control of terms and conditions and private law enforcement. This is also the reason why the fallback option of providing access via the already existing customer ASPSPs interface as opposed to direct access via APIs was criticised as not completely eliminating the perceived competition issues. ${ }^{150}$ This is not only the reason why the access-to-account rule could not be substituted with the data portabili-

regulatory gaps and addressing competition and data protection issues with regard to newly arising third-party payment services.

148 See on the market failure behind the data portability right enshrined in Art. 20 GDPR, Schweitzer and Peitz (n. 146) 50.

149 See Deutsche Kreditwirtschaft, Bundesverband der Deutschen Volksbanken und Raiffeisenbanken e.V., Deutscher Sparkassen- und Giroverband e.V., Bundesverband Deutscher Banken e.V., Sofort GmbH, giropay GmbH, Bundeskartellamt, 29 June 2016, Case 4 - 71/10, 4 <www.bundeskartellamt.de/SharedDocs/Entscheidung/D E/Entscheidungen/Kartellverbot/2016/B4-71-10.pdf?_blob=publicationFile\&v=4> accessed 31 August 2020.

150 See on the issue of direct and indirect access via already existing interfaces, position statement of the BKartA, 'Stellungnahme des Bundeskartellamts zu dem Gesetzesentwurf der Bundesregierung - Entwurf eines Gesetzes zur Umsetzung der zweiten Zahlungsdiensterichtlinie - BT-Drucksache-18/11495‘ (21 April 2017) <www.bundestag.de/resource/blob/503786/d5ae19e200f8d617a2ae0797d23 ba0cb/03-data.pdf $>$ accessed 31 August 2020. 
ty right under Article 20(2), (1) GDPR, ${ }^{151}$ it also makes clear that the PSD2 access-to-account rule goes beyond the GDPR's data portability scope of transmitting personal data in order to increase consumers' data sovereignty.

\section{Adverse effects on privacy, competition and innovation - the need for new asymmetric regulation}

Considering the information that PISPs can obtain and use under the access-to-account rule, namely the confirmation of payment execution, adverse effects on consumer sovereignty and choice seem unlikely. Even though the payment executions provided by PISPs may give insights into the purchasing behaviour of customers, the information gathered from the PIS does not have the same potential for algorithmic governance that account information does, for instance. Moreover, there are certain limitations enshrined in the PIS data governance regime that not only limit the actual available information but also restrict the options for possible use of this information in other data value chains. ${ }^{152} \mathrm{New}$ technical innovations with regard to cryptographic measures can also guarantee that data are actually not used for any other purpose, e.g. ML-enabled profiling and algorithmic governance. ${ }^{153}$ As the available information together with such us-

151 The two regimes are applicable in parallel, though the scopes of their provisions are not identical. See Article 29 Working Group, 'Guidelines to the right of data portability’ (5 April 2017) $7<$ http://ec.europa.eu/newsroom/document.cfm?doc_ $\mathrm{id}=44099>$ accessed 31 August 2020. It is questionable though whether the information needed falls under provided information within the meaning of Art.20(1) GDPR and the condition of technical feasibility set out in Art. 20(2) GDPR together with the potential IP protection pertaining to APIs Art. 20(4) would exempt the banks from their duty. Here potential software copyright protection for APIs becomes not relevant as Art. 20(1), (2) GDPR does not refer to the direct access via APIs - contrary to the PSD2.

152 See Sec. 49(4) of the German Payment Services Supervision Act (ZAG), implementing Art. 66(3) lit. e), f), g) PSD2.

153 This is not embodied in the Regulatory Technical Measures and certainly one aspect that can hardly be efficiently enforced. Nonetheless, particularly the current discussion pertaining to Personal Information Management Systems are already taking such new technical measures into account. See, for instance, Bundesamt für Sicherheit und Informationstechnik, 'Technische Richtlinie für Kryptographische Verfahren: Empfehlungen und Schlüssellängen' (2020) BSI TR-02102-1 <www.bsi.bund.de/DE/Publikationen/TechnischeRichtlinien/tr021 02/tr02102_node.html $>$ accessed 31 August 2020. 
age restriction also seems to restrict the competitive advantages that stem from increased data access in PIS cases - particularly with regard to the use of $\mathrm{AI}$ in order to offer a fully integrated customer experience and thus better digital ecosystems - the likelihood of data-induced distortions of competition also seems to be low.

Yet the access-to-account rule gives PISPs the possibility to enter into a direct customer relationship, which enables digital conglomerates to implement the customer into their existing platform business models and to gather valuable insights into their purchasing behaviour. As this is a new source of information, it may provide knowledge that goes beyond that already gained from their data value chains. ${ }^{154}$ Customers' purchasing information is logically intertwined with available information about customer preferences, habits and conduct and is thus a valuable input for further data-driven innovation in the context of AI and inferred data in ML applications.

This however may not only give rise to further algorithmic governance, but it is also likely to reduce competition in the long run. Through the combination of payments data with the other customer profile data, digital conglomerates gain further market power and can play out their competitive advantages. This holds particularly true as not only the data in terms of scope and scale but also increasing technological advancements in AI, computing power and cryptography are predominantly aggregated by digital conglomerates and can hardly be achieved by anyone else. ${ }^{155}$ The value of combined data together with their financial strength and strong portfolio effects may deter others from entering digital markets where the digital conglomerates are already active or are likely to become active. In these markets business would not only require ex ante investments for achieving the same customer insights through ML applications, but also the lack of a digital ecosystem and strong network effects may make business for other competitors hardly lucrative anymore. These structural market entry barri-

154 This is exactly the reason why undertakings are currently changing their business strategies towards platform business models.

155 This could also be compared to a ring fencing strategy, where innovations are secured by blocking other competitors via extensive IP protection. In this context it is interesting to see who has filed the most AI specific patent applications WIPO (n. 27). On the relevancy of strategic market entry barriers and the role of ring fencing see for instance John Vickers and Donald Hay (eds) The Economics of Market Dominance (Basic Blackwell 1987) 24. 
ers together with strategic foreclosure behaviour of digital conglomerates, ${ }^{156}$ i.e. enveloping strategies and customer lock-ins, may distort competition in the long run. This is likely in the case of 'Big Tech' banking. ${ }^{157}$ Once consumers stop multi-homing and instead concentrate their business on the digital conglomerate's single platform it will be more convenient for customers to stay within the same ecosystem and to also concentrate their banking system on this platform. This will likely affect most retail banking markets, for instance customer and SME lending markets, where borrowers will most likely act via the platform and not an incumbent bank's online or offline distribution channel. ${ }^{158}$ This lock-in effect is even exacerbated by the fact that the platforms dominate the front-end customer relationship and serve as an information intermediary, which enables them to favour their own or 'pay for display' services. Even though in Google Search (Shopping) (159 $^{2}$ and Google AdSense ${ }^{160}$ the European Commission found that Google's conduct of favouring the display of its own services or blocking other service providers from providing the same service infringed Article 102 lit.b) TFEU, it is unclear to what extent self-preferencing - if there is a dominant firm - really constitutes an abuse of dominance. ${ }^{161}$ Yet experience has already shown that digital conglomerates apply enveloping strategies, which lead to an increasing monopolisation of the Asian payments and retail banking market, for instance, where players take advantage of high network effects. ${ }^{162}$

156 Cf. Jay P. Choi, 'Tying in two-sided markets with multi-homing' (2010) 58 Journal of Industrial Economics 607.

157 Cf. de la Mano and Padilla (n. 106) 507.

158 Cf. Matthew Quint, David Rogers and Rick Ferguson, 'Showrooming and the rise of the mobile assisted shopper' (2013) $11<$ https:/www8.gsb.columbia.edu/g lobalbrands/sites/globalbrands/files/images/Showrooming_Rise_Mobile_Assiste d_Shopper_Columbi-Aimia_Sept2013.pdf accessed 31 August 2020.

159 Google Search (Shopping) (Case AT.39740) Commission decision of 27 June 2017 [2017] OJ C9/11.

160 European Commission Press Release, 'Commission fines Google €1.49 billion for abusive practices in online advertising' (20 March 2019) <https://ec.europa.eu /commission/presscorner/detail/en/IP_19_1770> accessed 31 August 2020.

161 Google appealed the decisions and pled to the General Court. Cf. on a critical side Bo Vesterdorf, 'Theories of Self-Preferencing and Duty to Deal - Two Sides of the Same Coin' (2015) 1(1) Competition Law and Policy Debate 4; in favour of an abuse see Nicolas Petit, 'Theories of Self-Preferencing Under Article 102 TFEU: A Reply to Bo Vesterdorf (2015) Competition Law and Policy Debate 1.

162 It can already be seen in Asia and the rise of Ant Finance how digital conglomerates impact the retail-banking sector. It also has to be noted that in Europe digital conglomerates already entered certain markets in the financial sector. Google 
Even though there are defensive strategies in theory, they will most likely not be successful in the case of Big Tech banking. If these conglomerates' competitors were to increase their cooperation with other third parties, transforming their business models into shared open platforms in order to benefit from co-investments and data sharing among all platform participants, this may not only raise concerns under Article 101 TFEU, ${ }^{163}$ the shared platform will most likely not scale up and be able to assemble a comparable bundle of services that could compete with the digital ecosystem of the digital conglomerate. Moreover, the matching of the digital conglomerates' bundling strategy with the strategic use of customer insights is unlikely, as the competitive advantages of digital conglomerates seem unassailable. ${ }^{164}$

Indeed, the rise of FinTech has positioned the bank as an intermediary for account holders and TPPs thereby including digital conglomerates. Thus, it is rather the digital conglomerate being integrated in the platform business model of the retail bank and not the other way around. This may not hinder the digital conglomerate from bundling its own platform's functionality with that of the retail banks so as to leverage shared user relationships and increase its enormous data-specific competition advantages. ${ }^{165}$ This might not prevent entry in markets with high regulatory entry barriers ${ }^{166}$ and markets that are still lacking customer demand for digital financial services. And yet the aggregated information may strengthen their digital ecosystem to such an extent that other digital markets with strong network effects may tip in favour of the digital conglomerate. Due to their gained knowledge, they may eventually provide better services,

already allows customers to make online payments via e-mail (Google Wallet), Amazon is offering loans within its platform (Amazon lending) and Apple Pay has begun to integrate payments in its touch authentication device. Also, Facebook has tried to launch its cryptocurrency 'libra', which still lacks authentication from European Financial Supervisory Authorities.

163 Cf. Case C-238/05 Asnef-Equifax ECLI:EU:C:2006:734.

164 De la Mano and Padilla (n. 106) 509; Eisenmann, Parker and Van Alstyne (n. 106).

165 See Joint Committee of the European Supervisory Authority (n. 134) 6; Milanesi (n. 116) 22. For a dissenting opinion see Anja Lambrecht and Catherine E. Tucker, 'Can big data protect a firm from competition?' (2017) Competition Policy International $<$ www.competitionpolicyinternational.com/can-big-data-protect-afirm-from-competition/> accessed 31 August 2020.

166 Credit institutes for example have more additional fiduciary duties and liabilities and need another, more costly licence, which requires high credit deposits and insurances. 
which will attract more users, leading to both direct and indirect network effects on both sides of the platform. ${ }^{167}$ It is thus important to assess the negative competition effects of further granting access on a strictly reciprocal basis.

Therefore, access regimes for PIS must be limited and the access right asymmetrically restricted. Even though the solution of cross licensing data may tackle the competitive disadvantages vis-à-vis digital conglomerates, the question inevitably arising is whether data protection laws may eventually render this solution impractical.

This might make a special preventive restriction of access for digital conglomerates together with an amendment of the financial supervisory laws (the data governance provisions) necessary. Access should be excluded for 'undertakings of paramount importance for competition across markets'. ${ }^{168}$ Such preventive ban with an authorisation option would make a case-by-case decision possible. This would then guarantee a better balancing of interests, i.e. the undertaking's right to freely conduct a business and to enter into the payments market and the general interest of safeguarding competition against the backdrop of sector-specific peculiarities (particularly data governance rules) and potential productivity efficiencies. With regard to the latter, the onus of proof would lie with the undertaking seeking access. The supervisory laws should therefore be adapted accordingly. This also requires further intra-agency collaboration between the Federal Financial Supervisory Authority and the BKartA. As some of these undertakings already operate in the market, the question ultimately arising is whether such undertakings should be banned. Either way, such considerations could also provide guidance with regard to new sector-specific data governance regulation that may justify different outcomes.

167 Cf. Facebook, BKartA, 15 February 2019, Case B6-22/16 <www.bundeskartellamt .de/SharedDocs/Entscheidung/DE/Entscheidungen/Missbrauchsaufsicht/2019/B6 -22-16pdf?_blob=publicationFile\&v=8> accessed 31 August 2020.

168 As stated in Sec. 19a GWB. 


\section{Account information services}

\section{Overview}

Under the notion of 'open banking', ${ }^{169}$ retail banking is increasingly focusing on sharing data in order to increase transparency, efficiency of incumbent businesses, competition and innovation in the banking and financial services industry. Moreover, the use of data is intended to create a more personalised customer experience and more compelling customer engagement, as well as greater control of customers over their data. ${ }^{170}$ Though financial players have always used data to make business decisions and reduce operational costs, the use of consumer financial data and account information, including for innovative complementary products and services, is constantly growing. The variety of data-driven services and products is immense and the advancements in AI that come with increased data from related sources, computing power and data scientists' know-how has further spurred data-driven innovation in the retail-banking sector. ${ }^{171}$

169 See Competition and Markets Authority (CMA), 'What Is Open Banking? Competition and Markets Authority Retail Banking Market Investigation: Infographic' (2016) < https://assets.publishing.service.gov.uk/government/uploads/system/u ploads/attachment-data/file/908412/what-is-open-banking.pdf $>$ accessed 31 August 2020, stating that open banking means reliable, personalised financial advice, precisely tailored to a customer's particular circumstances and delivered securely and confidentially. Cf European Banking Association (EBA) - Open Banking Working Group, 'Open Banking: Advancing Customer Centricity Analysis and Overview' (2017) $16<$ www.abe-eba.eu/media/azure/production/147 4/euro-banking-association-analysis-focuses-on-open-banking-advancing-custome r-centricity-1.pdf $>$ accessed 31 August 2020.

170 For instance, some of these products and services enable the provision of realtime information, which helps consumers make better-informed and more efficient decisions about spending, saving and borrowing. Others enable consumers to view and manage their financial account information on a consolidated basis across multiple accounts and financial institutions, thus giving them the convenience of a holistic overview of their financial activities. Some leverage automation and insight to help consumers achieve their savings or budgeting goals or to profile consumers and develop behavioural-based services or provide for better strategic decision making; others facilitate more targeted investment, financial planning and portfolio management solutions or simply support compliance with regulatory requirements by firms or back-test software solutions.

171 See Open Data Institute, 'Introducing the Open Banking Standard. Helping Customers, Banks and Regulators Take Banking into a Truly 21st Century, Connected Digital Economy' (2016) $2<$ https://dgen.net/1/Introducing-the-Open-Banking 
In the past a lot of data-driven services have been conducted through data access via screen scraping. ${ }^{172}$ Such technology raised challenges and risks for consumers and the incumbent banks that led to further regulation. ${ }^{173}$ These challenges were related not only to cyber security issues, as authentication credentials were passed over the internet and no secure communication could be guaranteed. The trend also created certain qualitative shortcomings with regard to the offered services, as data might be out-dated. Moreover, it posed the threat for incumbent banks that access to data may be abused - as typically banks were not aware of third parties entering the customers' online accounts. ${ }^{174}$ This in turn also caused data protection issues with regard to the excessive use of personal data of consumers.

To respond to this development, the EU decided to pave the way for secure Open Banking via the PSD2 and established a data governance regime with regard to account information services in order to provide consumers with adequate protection of their payment and account data. ${ }^{175}$ Therein, TPPs are first of all obliged to authenticate themselves before accessing data and secondly obliged to communicate solely via banks' communication interfaces. ${ }^{176}$ This in turn led to a ban of the screen scraping technology and actually as a result created factual data exclusivity with regard to the account information. The legislature further introduced a data access right

-Standard.pdf $>$ accessed 31 August 2020; Joint Committee of the European Supervisory Authority (n. 134) 10.

172 Screen Scraping is a practice of collecting ('scraping') data from the consumer's account information environment. There are two forms of screen scraping, server-based screen scraping and client-based screen scraping. In both scenarios, consumers shares their bank authentication credentials with a FinTech company, which passes them on to a data aggregator and then deletes them from its own records. The data aggregator stores the consumer's bank authentication credentials and creates an associated UID. In the server-based screen scraping scenario the data aggregator enters the credentials (UID) into the bank's website and scrapes the required consumer data. In the client-based scenario, the data aggregator passes the bank authentication credentials to a small application on the consumer's local computer, which then redirects the bank authentication credentials to the bank's website.

173 See on the challenges and risks associated with screen scraping Milanesi (n. 116) 34.

174 Here the banks typically have tried to exclude screen-scraping technologies via individual contract clauses or terms and conditions. As already mentioned above (n. 149) this was deemed to infringe Art. 101(1) TFEU.

175 Recital 28 PSD2 (n. 10). It has to be further noted that the legislative process of the PSD2 took place before the European Parliament adopted the GDPR.

Art. 67(2) lit. b), c) PSD2 (n. 10). 
for account information service providers. According to this right, payment service users can make use of services enabling access to account information, i.e. account information services (AISs), once the account is accessible online. ${ }^{177}$ This is again not dependent on any contractual relationship between the ASPSPs and AISPs. ${ }^{178}$

In contrast to PIS, inferred data from account information is typically part of the value chain of AIS. However, it is not clear what services fall under the term 'account information services' and whether this term really only covers services that build on inferred knowledge from the analysis of the account information. ${ }^{179}$ As already outlined above, AIS can only be considered data-driven innovation once data are actually used and not only aggregated. ${ }^{180}$ The question arising is therefore whether account information services ought to be narrowly interpreted and should only cover such services that provide additional knowledge to the payment service users similar to the new-product rule - or whether it may also encompass functionally equivalent information services that may not build on inferred data. Here, the PSD2 further elaborates in its recitals that the user should be 'provided $[. .$.$] with aggregated online information' in order to be 'able to$ have an overall view of its financial situation immediately at any given moment'. ${ }^{181}$ The German legislature actually defines account service provider as an online service that provides 'consolidated' - instead of 'aggregated' information. ${ }^{182}$ By this deviation from the PSD2 it may favour a more narrow interpretation of 'account information service'.

\section{Lack of investment incentives and the need for maintaining market options for incumbent banks}

A narrow interpretation is justified against the backdrop of the innovation incentive function of factual exclusivity and the incumbents' right to freely conduct a business. As AISs build on the data and the embedded account

177 Art. 67 PSD2 in conjunction with Annex I (8) PSD2.

178 Art. 67(4) PSD2 (n. 10).

179 Arts 4(10), 67(1) PSD2 (n. 10) only refer to Annex I (8) PSD2 that clarifies that account information services are considered payment services in the meaning of Art. 4(3) PSD2.

180 Cf. OECD (n. 21).

181 Recital 28 PSD2 (n. 10).

182 Sec. 1(34) German Payment Services Supervision Act (ZAG) defines account information service as 'Onlinedienst zur Mitteilung konsolidierter Informationen'. 
information, the quality of data is the key value-adding factor of the service. Data quality has various dimensions and quality indicators. ${ }^{183}$ Particularly with regard to AIS it is important that data are timely, credible, accurate, consistent and complete. Even though the RTS Delegated Regulation set out an obligation for AIPSPs to keep their communication interfaces interoperable and thus declares the sharing of interoperability information at no charge as a mandatory prerequisite for enabling AIS, ${ }^{184}$ they do not regulate data standards. Therefore, particular data semantics and thus the subject of the mandated access regimes can still be freely determined by the ASPSPs and are not unequivocally defined by the access regime. Even though private ordering has already led to the implementation of certain data standards, semantic interoperability is still not thoroughly addressed in the current data standardisation framework with regard to account information. This may eventually de facto hinder data integration and the efficient provisioning of AIS - despite the access-to-information rules outlined in the PSD2 and the RTS Delegated Regulation that do not explicitly define a direct access right of competitors. ${ }^{185}$ As the mandated access regime eliminates the ASPSPs' market options with regard to potentially monetising account information, this may not only reduce market and competition-driven data quality in this context, it may also negatively impact further data-driven innovation that is conducted by the incumbents. Input aggregation and factual data exclusivity is particularly important with regard to further data-driven innovation enabled by AI. ${ }^{186}$ As there exists legal uncertainty to what extent IP laws may still be applicable to $\mathrm{AI}$ as a tool and $\mathrm{AI}$ generated output, input aggregation may be one of the key factors of firm's innovation strategies. ${ }^{187}$ Once data may be shared with others - and data-rich digital conglomerates in particular this may leave the incumbents with fewer incentives to generate high-quality data. As regulation is not remedying such loss of incentives by establish-

183 See for an overview of different data quality categories and the existing standards under the ISO-8000 data standard Cai and Zhu (Fn. 28) 5.

184 See Art. 30(3) RTS Delegated Regulation (n. 127). This becomes particularly interesting as the software copyright protection outlined in Article 6 Directive 2009/24/EC of the European Parliament and of the Council of 23 April 2009 on the legal protection of computer programs (Codified version) [2009] OJ L111/16 and Sec. 69e of the German Copyright Act pertaining to APIs or other communication interfaces is, as of now, not clear.

185 Art. 36(1), (4) RTS Delegated Regulation (n. 127) set out both obligations, the duty to provide information and the duty to let AISPs access information.

186 See Hilty, Hoffmann and Scheuerer (n. 20) 21.

187 Ibid. 
ing the same data-quality standards, too broad data access should not be mandated. In this context, however, it must be noted that before the AIS data governance regime entered into force, banks were already exposed to third-party access to the customer accounts via screen scraping.

Moreover, the AIS access regime sets out further restrictions with the same purpose limitation as for PIS and thus also limits the multipurpose use of the data. Yet the account information service itself may already provide the undertaking seeking access with such knowledge that might lead to a competitive disadvantage for the ASPSPs vis-à-vis the AISPs. Similar to PISs, most of the operational risks and costs associated with such access are still unilaterally borne by the ASPSPs. Therefore, a narrow interpretation of the term 'account information services' is needed. To this end, functionally equivalent information services should not fall under the definition of account information services. As already outlined above, assessing whether information services are a functional equivalent may be a hard task to fulfil - particularly when AI is involved. Here, it should only be assessed whether the information service provided obviously offers the same information service. ${ }^{188}$ This should also be borne in mind when defining consolidated information in the German access provision.

With regard to possible remuneration for granting access, the same explanations as outlined above can be applied mutatis mutandis. If access is mandated and the factual data exclusivity eliminated, it is necessary to maintain the right to exploit the granting of access via potential remuneration options. This will not only safeguard some market and competitiondriven incentives for generating better quality data, it will also appropriately confine the undertakings' right to freely conduct a business. Here, it is questionable whether FRAND licensing regimes are needed or whether simply mechanisms to control excessive pricing under general competition law can be sufficient.

With regard to the role of direct innovation-enabling regulation on data-driven innovations, it has to be noted that before the PSD2 entered into force banks and other account providers already used to provide account information services to their customers. Third parties either directly collaborated with banks and other account providers or entered into a chain of contract with aggregators that again have a contract with the respective bank or account provider. Ultimately, third parties could also operate through data access via screen scraping. Only by introducing the authorisa-

188 This could be similar to the inventive step four-step approach regarding the nonobviousness of the invention applicable in the UK. 
tion duty, they actually create factual exclusivity of the account information, which then makes an access regime necessary. In this light, the AIS data governance regime could also be seen as only mitigating the risks that were associated with the screen scraping techniques and establishing a secure way of communication but in principle maintaining the market situation as it was. However, with the introduction of the access-to-account rule and the portability right applicable to AISs, the legislature also imposed mandatory access that eliminated any market option for the ASPSPs. The access-to-account rule restricts the ASPSPs' right to freedom of contract that should be typically safeguarded by competition laws and not destroyed by ex ante regulation, which abstains from a competition policy approach. As already outlined above, however, this ultimately depends on the relevant market with regard to the account information needed. If account information cannot be substituted and are indispensable, there are exceptional circumstances that justify the mandatory granting of access under certain conditions. Otherwise factual data exclusivity would result in monopolisation over account information that would lead to a bargaining power asymmetry, making effective decentralised decision-making between parties impossible. This point always depends on the existent market structure - as unlike Art. $20 \mathrm{GWB}$ that follows the rationale of unfair competition laws - relative market power still does not constitute an abuse of dominance under Art. 102 TFEU. As long as there is enough system competition within the retail payments market there should be enough possibilities to enter -freely-into licensing contracts. Only if this is not the case, the legal intervention and a more centralised decision-making - as in the PSD2 access-to-account regulation on AIS - is justified. It must be noted though that legislative intervention should be kept to a minimum and should not inappropriately infringe the ASPSPs' right of to freely conduct a business. This not only requires a narrow interpretation of what constitutes account information services and the entire modalities of access, it further makes the remuneration possibility for ASPSPs necessary.

The conflicting data protection dimension behind data access regulation again may attenuate these considerations. As the data portability right enshrined in Article 20(2) and (1) GDPR establishes a right that aims at safeguarding data sovereignty with a limited remuneration option, ${ }^{189}$ these two regimes may be conflicting if personal data of data subjects are involved and thus may need to be aligned. Both legal regimes are deemed

189 Data should be provided for free as long as no excessive use of the right is made: Art. 12(5) GDPR. 
to be applicable in parallel. ${ }^{190}$ Both regimes provide consumers -the PSD2 also merchants - with a right to data portability. ${ }^{191}$ The scope of the rights, however, varies, as the modalities of data portability and access are differently outlined. The PSD2 access regime for AIS goes beyond the GDPR's data portability regime as it further creates an access-to-account option for AISPs and it does not restrict the data access and portability right to cases where it is technically feasible, as does Article 20(2) GDPR. ${ }^{192}$ The narrow interpretation of the access-to-account rule for AIS under the PSD2 together with an option of remuneration is therefore justified.

\section{Tackling BigTech banking by introducing new asymmetric regulation}

Unlike the information in PIS, account information is relevant when it comes to gauging potential adverse effects of a too-broad data access regime with regard to algorithmic governance and data-induced distortions of competition. Transaction history and payments information may not only allow for conclusions about customers' purchasing behaviour, it also indirectly provides multiple other behavioural insights, e.g. into customers' personal life and emotions or risk affinity. This in turn provides exactly the source of information on which further algorithmic governance can build on and thus is also the reason why such information can be considered highly relevant for competition.

There are two legal restrictions regarding the further use of data, though that need to be considered. The PSD2 itself has already restricted further usage options. Moreover, account information is personal information, which makes data protection rules relevant. ${ }^{193}$ Both restrictions already

190 See Article 29 Working Group (n. 151).

191 It is unclear whether according to the data portability right enshrined in Art. 20(2) and (1) GDPR competitors can also invoke the right directly or it can only be invoked by the consumers.

192 Technically feasible requires less in order to perform than factual impossibility would require. The latter is typically needed for the performing party to be exculpated.

193 Art. 94(1) and (2) PSD2 (n. 10) and Sec. 59(3) German Payment Services Supervision Act $(Z A G)$ explicitly refer to the applicability of data protection rules. Even though the PSD2 only refers to Data Protection Directive 95/46/EC, the GDPR is still applicable in parallel. 
prevent anti-competitive effects - at least to some extent - as data can only be further used to the extent outlined in both legal regimes. ${ }^{194}$

Both the PSD2 and the German legislature have implemented usage restrictions pertaining to account information limiting the use of information to the respective account information service explicitly requested by the payment service user. ${ }^{195}$ The narrow usage restriction only evolved in the course of the law-making process. The European Commission's first draft of the PSD2 ${ }^{196}$ did not mention any such limitation. At an intermediate stage further use was made dependent only on the explicit will of the customer, and then, in its final version, the usage restriction was drafted even more narrowly, as outlined above. ${ }^{197}$ Here it is not clear whether such restriction should only give rise to data protection considerations and might thus be overridden by the contrary explicit consent of the payment service user. In light of the above-mentioned considerations, this should not be possible, as the adverse effects of such broad interpretation would likely occur. This also makes any contractual exclusion of the usage restriction impossible.

Such restriction of use however could potentially be in conflict with the GDPR's data portability regime, as the portability regime may further en-

194 This was already acknowledged by the European Commission in Verizon/Yahoo (Case COMP/M8180) Commission decision of 21 December 2016 C(2016) 8978 final. In this case both Verizon and Yahoo used certain data generated by user activity on their websites, apps and other services such as their ad networks to improve their online advertising services (e.g. sold to advertisers and publishers) and better target advertising on websites and apps. The EC saw two issues concerning these online advertising services as a result of the combination of the two datasets previously held independently by Verizon and Yahoo: (i) the increased market power of the merged entity; and (ii) the elimination of competition based on the data that existed between Verizon and Yahoo prior to the merger. See also Sanofi/Google/DMI JV (Case COMP/M.7813) Commission decision of 23 February $2016 \mathrm{C}(2016) 1223$ final.

195 Art. 67(2) lit.f) PSD2 (n. 10), Sec. 51(1) German Payment Services Supervision Act $(Z A G)$ both state that the information should not be used, accessed or stored for any other purpose than for performing the account information service explicitly requested by the payment service user.

196 See Art. 58(2) lit. d) Proposal for a Directive on payment services in the internal market $\operatorname{COM}(2013) 547$ final.

197 The first draft of the PSD2 lacking usage restriction was already criticised by the European Data Protection Supervisor and the European Central Bank for being not compliant with data protection and IT security standards. Almost one year after the first adaption of the first usage restriction amendment, the Committee on Economic and Monetary affairs further amended the usage restriction to its final version. 
able the transmission of data to digital conglomerates that are already subject to the special competition control regime. This is another tension where the consumers' data sovereignty and individual interest conflict with the goal of protecting competition and innovation. This needs to be reconciled by limiting the portability regime and addressing this issue on a supranational level.

Moreover, the AIS itself could already have the same effects as potential further use of the account information. The subject of the service may already constitute what is considered algorithmic governance or another step for further consolidating digital ecosystems. Therefore, one should also consider asymmetric regulation vis-à-vis digital conglomerates and thus apply the abovementioned considerations pertaining to PIS mutatis mutandis in the case of AIS.

\section{Conclusion}

Although enhanced access to data has positive welfare effects and further spurs data-driven innovation, there are five points that must be considered.

First of all, any regulatory approach pertaining to data access on a B2B level needs to build on a regulatory theory that takes the multi-purpose functions of data as its starting point. Only such comprehensiveness may enable the legislature to fully grasp the multi-dimensional implications of data and the regulation of compulsory access and their potential adverse effects.

Second, the notion of data-driven innovation - particularly in the context of AI - should not be too heavily relied on as a blanket justification for overly broad access regulation. It must be considered, under both innovation incentives and the undertakings' fundamental right of freely conducting a business, that the openness of data should not be considered as the default rule. In this context, both the economic and the legal analysis show that access should and has generally only been granted under exceptional circumstances. Therefore, it is important to align any sector-specific data access regulation with the general competition-law thresholds - also with regard to remuneration options. Moreover, investment incentive considerations may require a restriction of data access to services that are not a functional equivalent to the data or data-driven service already provided. Too broad access regimes might also have negative effects on the levels of quality of the data. This ultimately depends on sector-specific data governance regimes that provide some basic guarantee of a certain level of data quality. In this context, however, the role of (semantic) interoperability is a 
key factor for welfare-enhancing data spill-overs that has not been considered sufficiently.

Third, under the orthodoxy of a free market economy one has to abstain from too heavy-handed ex ante access regulation and choose a more competition policy specific regulatory approach. Innovation should be market force-driven and not subject to mere industrial policy considerations. Competition still leads to market equilibria in which dynamic efficiencies are typically inherent in the coordination process of market actors. Better engaging customers in order to tackle the inertia of customers to value specific digital services and enable competition on certain non-salient products or certain product parameters is key. This potential behavioural market failure, however, cannot be remedied by mandating overly broad access to data.

Fourth, once there are personal data involved, data protection considerations become intertwined with the factual exclusivity of data and the role of - indirectly - granting access to competitors. Empirical studies have shown that a consent-based data protection solution still gives undertakings the chance to analyse data and eventually create such knowledge that may not only unconsciously influence consumers but also generate enormous competition advantages. Even though paternalistic approaches are currently being discussed that would tackle the bounded rationality of consumers who seem not to value privacy, not granting access or specific data use restrictions may be a more efficient solution for preventing further algorithmic governance - that may also negatively affect both competition and innovation.

Fifth, enhanced access to data - particularly for already data-rich undertakings - has to be assessed against the backdrop of potential disruptions of competition even across markets, and it thus reinvigorates the role of ex ante market regulation. Potential ways forward may be asymmetric regulation, restricting the parties entitled to access data, or a specific preventive competition control regime for 'undertakings of paramount importance for competition across markets' - as outlined in the $10^{\text {th }}$ amendment of the GWB and in the Digital Markets Act. In this context the (enormous) productivity efficiencies, the thin line between competition on the merits, safeguarding the competition process per se and establishing non-competition specific market regulation detached from market concentrations considerations need to be thoroughly assessed and cautiously defined.

When it comes to the access regimes applying to PIS and AIS it is important to note that both regimes have to be differently assessed as the role of data within these services varies tremendously. The PIS regime provides a direct access right for customers and fails to sufficiently address the legal 
relationship between ASPSPs and PISPs. Yet, any direct access right of costumers together with the obligation of the ASPSPs to grant access provides indirect access for competitors. It remains questionable though how competitors can enforce such indirect access possibility. The implementation of the PSD2 in Germany in both public and private laws not only unveils the tensions between private and public interests in these cases, it further creates legal uncertainty regarding the different rights and obligations of all the parties involved. A more dogmatically consistent implementation of the PSD2 into German law would have been desirable. The access to account for PIS is granted below the competition specific thresholds outlined above and is thus another policy-driven attempt of direct market intervention to shape certain markets for FinTech-driven innovation. The negative consequences on the quality of services, however, seem to be rather low as the data governance regime outweighs a potential lack of incentives. This should not divert attention from the fact that asymmetric financial supervisory regulation and the access-to-account rule together provide new entrants with so great an advantage that it makes negative effects on competition even across markets likely, with a possible impact on dynamic efficiencies and financial stability. Therefore, a remuneration option for ASPSPs vis-à-vis TPPs should be possible and asymmetric regulation regarding 'undertakings of paramount importance for competition across markets' considered. This may make an alignment of the two regimes and the data portability regime under Article 20(2), (1) GDPR necessary. With regard to AIS, the same considerations regarding the lack of directly addressing the legal relationship between ASPSPs and AISPs apply mutatis mutandis. Moreover, it is crucial that the economic and legal competition considerations pertaining to refusal-to-deal cases should be reflected in the interpretation of AIS. This may even require - contrary to the Microsoft case - under economic considerations a limitation of the access regime to non-functional equivalent account information services. This has been partly foreseen by the German legislature. However, also in this case, a remuneration option and the asymmetric regulation for digital conglomerates should be guaranteed.

The PSD2's regulatory model of sector-specific access and governance regimes can serve as a good starting point for defining a legal framework that safeguards data-driven innovation. It already entails a data governance regime that correctly restricts further data usage options and has the ambition to establish secure communication standards. However, there are shortcomings. (Semantic) interoperability is still not sufficiently addressed, APIs are not standardised and are not the sole means of secure communication. Moreover, as already shown above, the PIS regime not only resem- 
bles a policy-driven approach of direct market intervention, both regimes for PIS and AIS - do not properly reconcile the different interests involved and do not take the various dimensions of data in this context into account, and thus need further regulatory adjustments.

The European Commission's envisioned data strategy for the future, ${ }^{198}$ in which the role of the European legislature in further boosting the data economy entails refraining from fiat and focusing on promoting private ordering and private incentives for sharing data, should be supported. The European Commission rightly foresees the role of the EU as facilitating voluntary data sharing and abstaining from overly detailed, heavy-handed ex ante regulation. The latter ought to only be the case if it is doubtful that competition law can solve the identified market failure, and only if exceptional circumstances dictate compulsory access to data. Nevertheless, sector-specific data governance rules may require sector-specific solutions. This should not mean that sector-specific market regulation should deviate from a competition policy based regulatory approach. A competition policy approach does not only better reconcile the different interests involved it also safeguards innovation in the long run. Here - again - it should be added that any data access regulation must reflect the different relevant dimensions of data and assess the regime in light of all potential adverse effects outlined above. This approach should be combined with a broader industrial strategy for a data-agile economy. The European Commission thereby rightly envisions investments in standards, tools and new infrastructures - like data trusteeship models or GaiaX. In particular, the standardisation of data models and APIs need to be on the agenda.

198 See Commission, 'A European strategy for data' (n. 4). 